\title{
ТЕРЕНТИЙ ИВАНОВИЧ ВЯЗЕМСКИЙ (К 160-ЛЕТИЮ СО ДНЯ РОЖДЕНИЯ)
}

\author{
Михаленок Д.К. \\ 2. Феодосия, Российская Федерачия, dmikhalenok@gmail.com
}

Рассмотрены некоторые сферы деятельности доктора медицины, библиофила, основателя научной станции на Карадаге - Т.И. Вяземского. Т.И. Вяземский считал, что в основе развития общества должна находиться культура. В вопросах по борьбе с алкоголизмом он предлагал ряд пропедевтических мер, которые не утратили своего значения в наше время. Т.И. Вяземский принимал участие в работе Русского бальнеологического общества в Пятигорске. Его исследования в области электротерапии остаются актуальными. Он обнаружил важный исторический факт - определил, что годом основания Кавказских минеральных вод следует считать не 1798 г., а 1803 г. Дата считается общепринятой, а имя Т.И. Вяземского, определившего ее - забыто. Он собрал обширную библиотеку по многим направлениям естествознания, библиотека призвана была стать основой, краеугольным камнем в работе выстроенной им научной станции. В конце жизни пожертвовал станцию и библиотеку Обществу им. Х.С. Леденцова. На основе анализа архивных материалов и литературных источников раскрыты малоизвестные страницы биографии Т.И. Вяземского.

Ключевые слова: Карадагская научная станция им. Т.И. Вяземского, Общество им. Х.С. Леденцова, Кавказские минеральные воды, школьный алкоголизм, частная библиотека Т.И. Вяземского, имение «Карадаг».

\section{Введение}

В 2017 году исполняется 160 лет со дня рождения Терентия Ивановича Вяземского (1857-1914). Деятельность врача, ученого, библиофила, общественного деятеля, создателя научной станции в Крыму в достаточной мере в современной литературе не отражена и нуждается в подробном изучении. Имя известного в дореволюционной России практикующего московского врача основательно подзабыто (рис. 1).

Однако история науки не должна оставаться незыблемой и застывшей. Приведем слова выдающегося ученого Владимира Ивановича Вернадского (1863-1945): «История науки и ее прошлого должна критически составляться каждым научным поколением и не только потому, что меняются запасы наших знаний о прошлом, открываются новые документы, или находятся новые приемы восстановления былого, нет! Необходимо вновь научно перерабатывать историю, вновь исторически уходить в прошлое, потому что благодаря развитию современного знания в прошлом получает значение одно и теряет другое. Каждое поколение научных исследователей ищет и находит в истории науки отражение научных течений своего времени. Двигаясь вперед, наука не только создает новое, но и неизбежно переоценивает старое, пережитое» (Вернадский, 1912. С. 7).

Всматриваясь в прошлое и оценивая настоящее, убеждаемся, что собранная Т.И. Вяземским обширная

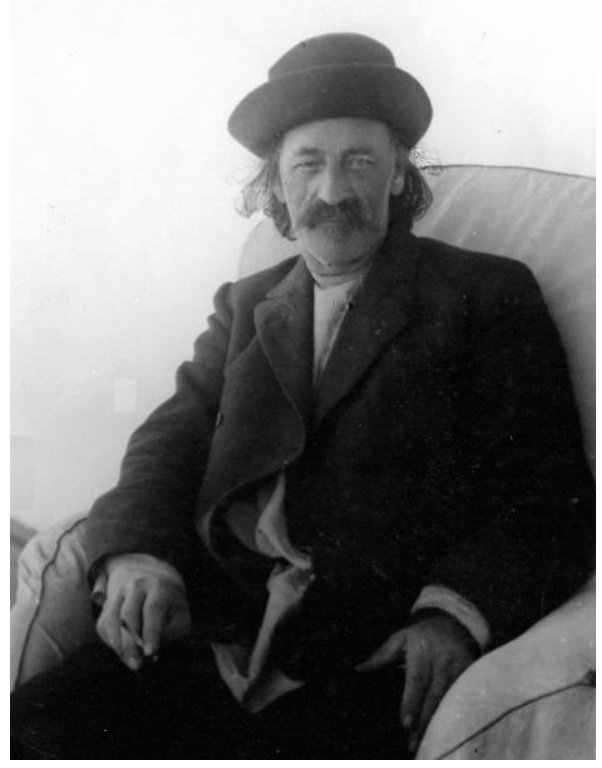

Рис. 1. Т.И. Вяземский. Фотография 1910-х гг. Архив Карадагской биологической станции. 
библиотека, представляющая собой культурную ценность, продолжает привлекать неослабевающее внимание исследователей. Научное сообщество проявляет живой интерес к работе Карадагской научной станции им. Т.И. Вяземского. Выразим надежду, что пришло время для объективной и всесторонней оценки деятельности Т.И. Вяземского, его вклада в культурное развитие общества.

\section{Методика исследований}

Применена методика источниковедческого анализа с привлечением общенаучных методов исследований: аналитического, синтетического, исторического (ретроспективного) (Медушевская, 1976).

Все даты указаны по старому (юлианскому) календарю.

\section{Результаты и обсуждение}

\section{О борьбе с алкоголизмом}

При рассмотрении исследований по вопросам алкоголизма в России понимаем, что разработанные Т.И. Вяземским предупредительные меры в борьбе с алкоголизмом были и остаются едва ли не самыми приемлемыми в современном обществе.

Напомним суть предложений, изложенных в работе «Возможна ли в России борьба с алкоголизмом» (Вяземский, 1911 a). Работа написана с большой любовью к человеку, а ее положения могут быть применимы, с учетом национальных особенностей, для ряда стран, где производится и потребляется алкоголь.

На законодательном уровне Т.И. Вяземский предлагал решить два важнейших вопроса: «Узаконить распивочно, но не на вынос». Этим алкоголь не допускается в семью.

«Абсолютно воспретить в места "распивочно" вход женщинам и детям до их совершеннолетия». Раскрывая суть второго вопроса, Т.И. Вяземский ссылается на исследования «лучших представителей медицинской науки» того времени (Там же. С. 10). Лучшие представители современной медицинской науки так же не склонны отвергать это положение.

Предлагаемая Т.И. Вяземским законодательная мера сводится к потреблению алкоголя распивочно в специально отведенных для этого местах и не производит радикальных изменений в организации «питейного дела». Эта мера направлена на спасение от вырождения будущих поколений и рассчитана на 20 лет. В течение этого времени государство организует и проводит воспитательную работу по борьбе с алкоголизмом во всех слоях населения. Через двадцать лет вырастает новое поколение с критическим отношением к потреблению алкоголя, а в целом трезвеннические убеждения формируются у всех возрастных групп. С обществом государство может уже вести диалог о введении запретительной системы. Т.И. Вяземский призывал к вдумчивому, осторожному применению запретительной системы: «Если по каким-либо финансовым соображениям не может быть через 20 лет введена запретительная система, то все же и при продолжении действий одного закона "на вынос" и запрещения женщинам и детям входа в места "распивочно" состав потребителей алкоголя будет постепенно меняться: число алкоголиков будет быстро падать». Это утверждение основано на данных Т.И. Вяземского, суть которых заключается в том, что если человек «начинает пить только после 20-летнего возраста, степень вероятия сделаться алкоголиком резко падает и она становится крайне ничтожной после 25-летнего возраста» (Там же. С 15-16).

Такой вдумчивый подход к решению проблем алкоголизма не был применен в России. Вместе с тем, опыт борьбы с алкоголизмом, основанный на нравственных началах и запретительной системе показал свою неэффективность в западноевропейских странах и США. Так же и в СССР.

Т.И. Вяземский рассматривал проблемы алкоголизма в более широком, общественном значении, в контексте социальных ядов, под которыми, помимо алкоголизма, он подразумевал: «сифилис, проституцию, туберкулез, никотинизм, пауперизм, преступность, болезненность, 
детскую смертность, вырождение, сумасшествие, самоубийство и т[ому] п[одобное]» (Субботин, 1914. С. 21). Он мечтал, чтобы эти важные и нужные вопросы освещались в одном научно-популярном журнале «для осведомления общества обо всех перечисленных факторах этой “социальной патологии” и для выработки надлежащих совокупных у общества с правительством, планомерных и настойчивых мер борьбы с ними» (Там же. С. 21). Товарищ Т.И. Вяземского, известный государственный деятель России Соломон Самуилович Крым (1867-1936), разделявший его убеждения, добился в правительстве России разрешение на издание и финансирование научно-популярного журнала (Крым, 1917. С. 16). К сожалению, последовавшая в 1914 г. кончина Т.И. Вяземского, остановила реализацию этого нужного дела.

Т.И. Вяземский стремился для блага человека перенести в общественное сознание достижения медицинской науки в области лечения алкоголизма и социальной патологии, но ожидаемых результатов по прошествии более ста лет мы не видим. Во многих странах, по сравнению с началом XX века, потребление алкоголя и наркотиков значительно возросло, что многократно ускорило процесс вырождения человечества. «Здесь лечащая медицина бессильна. - Остается лишь повторить слова, сказанные Т.И. Вяземским более ста лет назад, в 1913 г. в работе «Вырождение и алкоголизм». - Об этом громко говорит сам факт прогрессивного вырождения и вымирания современных культурных народов» (Вяземский, 1913. С. 1).

Т.И. Вяземский считал, что объектом пристального внимания должны быть дети и подростки. Только в результате многолетней воспитательной работы с детьми можно рассчитывать на отрицательное отношение к потреблению алкоголя у новых поколений. Такой подход разделял коллега Т.И. Вяземского, доктор медицины, врач невропатолог Александр Александрович Корнилов (1859-1926). В 1909 г. вокруг Т.И. Вяземского и А.А. Корнилова сформировался круг лиц, заинтересованных в пропаганде идей трезвости среди школьников. Назовем их имена: статский советник, инспектор народных училищ Московского уезда Гурий Феодосеевич Марков, член-соревнователь Московского столичного попечительства о народной трезвости И.В. Субботин, врачи - Л.П. Боголепов, Н.Д. Титов, М.Ю. Лахтин, А.И. Лянц, А.Я. Давыдов, В.Т. Попов, протоиерей Московского Успенского собора Н.А. Любимов, священники - С.Д. Богословский и Н.А. Преображенский. Все они принимали активное участие в создании «Кружка деятелей по борьбе со школьным алкоголизмом» (далее: Кружок). Название, быть может, несколько неожиданное. Однако, когда провели анкетирование по школам Московской губернии, то неожиданно выяснили следующее: более половины школьников не только потребляли спиртные напитки, но получали удовольствие от опьянения. Становится понятным, почему Кружок получил такое, на первый взгляд, необычное название. Для борьбы со школьным алкоголизмом организаторы Кружка решили ввести в школах преподавание науки о трезвости. Официально Кружок был создан в марте 1910 г. (Вяземский, 1911 б. С. 2-3).

Т.И. Вяземский предложил организовать при Кружке противоалкогольный музей. Идея нашла поддержку со стороны губернатора Москвы Владимира Федоровича Джунковского (1865-1938). Открытие музея состоялось 19 декабря 1910 г. До официального открытия музей посетила великая княгиня Елизавета Федоровна (1864-1918). Собрались организаторы Кружка. В торжественной обстановке протоиерей Н.А. Любимов произнес приветственную речь. Председатель Кружка А.А. Корнилов представил великой княгине присутствующих. С экспонатами музея великую княгиню знакомили врачи: Т.И. Вяземский, М.Ю. Лахтин, В.Т. Попов, Н.А. Флеров. Т.И. Вяземский, в частности, обратил внимание Елизаветы Федоровны на диаграммы, характеризующие отрицательное влияние спиртных напитков на психическую деятельность человека (Там же. С. 10). Завершая показ коллекций музея, Т.И. Вяземский, обращаясь к великой княгине, подчеркнул необходимость вмешательства государства в борьбу с алкоголизмом: «Если Государство тратит около 100 миллионов рублей на просвещение народа, а сам народ, по самоопределению, более миллиарда рублей тратит на свое затмение, на переполнение тюрем, психиатрических заведений, на вымирание и на вырождение в племя хилое, слаборазвитое, низкорослое, уже наполовину бракуемое при призывах к отбыванию воинской повинности, - при таких условиях вмешательство Государства 
безусловно необходимо». Эти слова вошли в работу Т.И. Вяземского «Возможна ли в России борьба с алкоголизмом» (Вяземский, 1911 а. С. 16).

Елизавета Федоровна с пониманием отнеслась к проблемам алкоголизма, осталась довольна посещением музея, расписалась в книге почетных гостей. «Пожелала полного успеха вновь возникшему учреждению; она высказала, что считает дело, которому посвятил свои силы Кружок, чрезвычайно важным, - и надеется, что познание вреда алкоголизма в школьном возрасте создаст трезвую молодежь». - пишет Т.И. Вяземский (Вяземский, 1911 б. С. 11).

Т.И. Вяземский хорошо знал отечественную и зарубежную литературу по различным вопросам алкоголизма. В 1909 г. он выпустил первую в России библиографию по алкоголизму (Вяземский, 1909). Библиография была приурочена к 1 Всероссийскому съезду по борьбе с пьянством, проходившем в Петербурге с 28 декабря 1909 г. по 6 января 1910 г. Книга вышла с посвящением С.С. Крыму (рис. 2). Т.И. Вяземский подготовил несколько тысяч библиографических карточек и планировал распределить материал на три выпуска. «Большие трудности, - заметил Т.И. Вяземский, - представляет самое распределение собранного мною материала. Одною из главных причин является оглавление работ. В зависимости от этого некоторые из этих работ в принятом мною распределении материала могли занять не соответствующее им место. Пользование этою библиографиею облегчится "Указателем предметным и по авторам", который будет приложен к последнему выпуску» (Там же. С. III). Первый выпуск библиографии содержал 1153 работы по различным вопросам алкоголизма. К сожалению, последующие выпуски издать не удалось. Однако и первый выпуск служил справочным материалом для нескольких поколений медиков (Поддубный, 1993. С. 35).

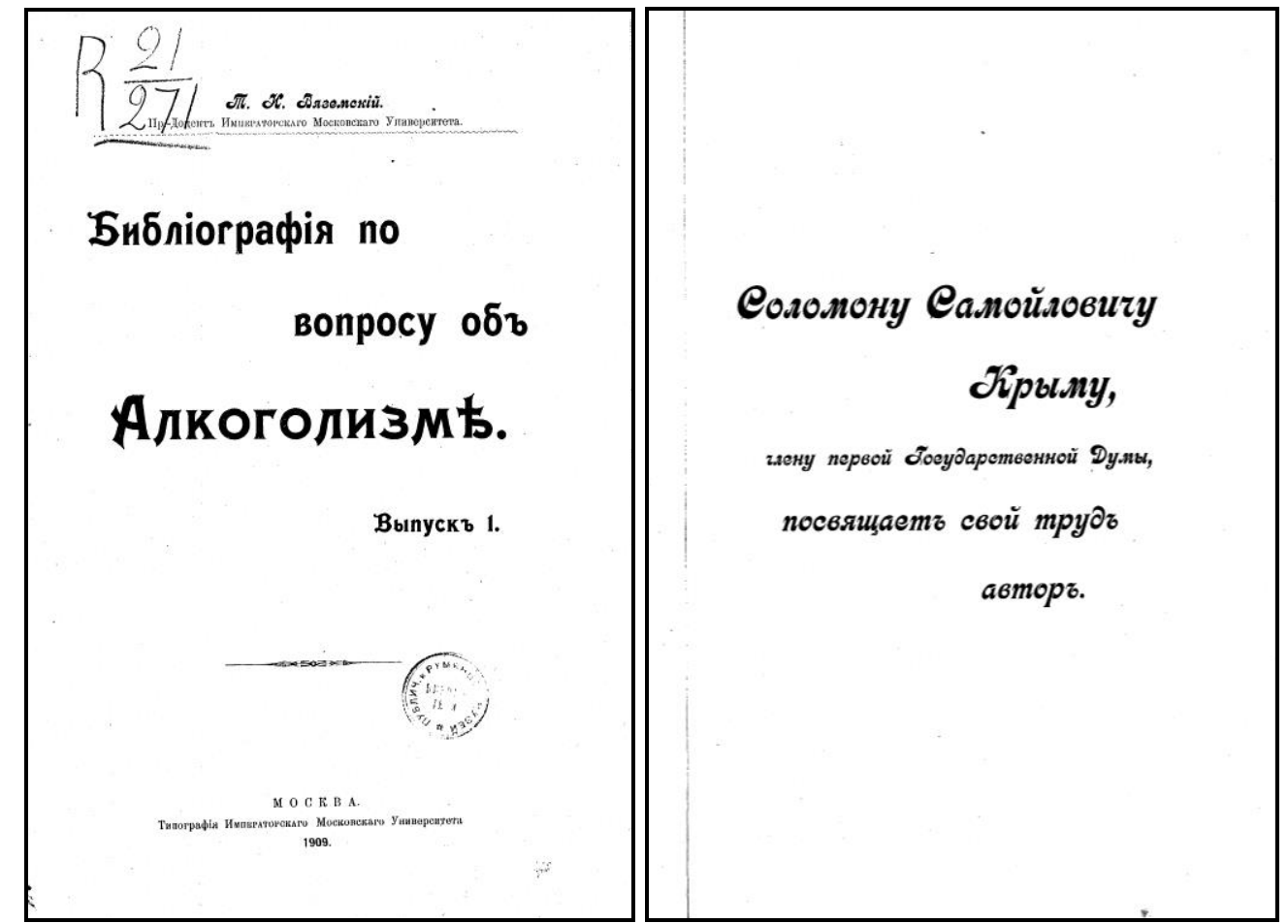

Рис. 2. Т.И. Вяземский. Библиография по вопросу об алкоголизме. - М., 1909. - Вып. 1, титульный лист и посвящение С.С. Крыму на с. [II].

С сентября 1911 г. Т.И. Вяземский стал врачом и одновременно преподавателем школьной гигиены в институте имени П.Г. Шелапутина. Институт с двухлетним сроком обучения был организован в 1911 г. одним из богатейших людей России Павлом Григорьевичем Шелапутиным (1847-1914) для усовершенствования знаний (повышение квалификации). Различным педагогическим дисциплинам обучались мужчины, имеющие высшее образование и готовившие себя к учительской деятельности в гимназиях. Преподавательская и врачебная деятельность Т.И. Вяземского в новом для России учебном заведении продолжались до конца 
его жизни. Коллега Т.И. Вяземского по Кружку И.В. Субботин об этом периоде вспоминал: «[...] [Т.И. Вяземский] часто говорил, что он всеми силами стремится воспитать в слушателях желание и интерес работать, по окончании ими курса, в пользу антиалкогольного воспитания юношества. Им для этого устраивались специальные коллоквиумы со слушателями, где обсуждались различные темы, основания и меры борьбы с алкоголизмом в России» (Субботин, 1914. С. 23). Краткий штрих к характеристике институтского врача Т.И. Вяземского дает директор института историк-медиевист Антон Никитич Ясинский (1864-1933). В записке от 30 мая 1913 г. он пишет: «[...] Надеюсь, что вечером вы зайдете ко мне; Вас жаждет видеть и благодарит мать больного [...] Разумеется, и мы все будем рады видеть Вас у себя. Остаюсь душевно преданный и глубоко Вас уважающий. Ант[он] Ясинский» (ЦИАМ. Ф. 1336. Оп. 1. Д. 144. Л. 2). В начале апреля 1914 г. Т.И. Вяземский заболел и не смог присутствовать в институте. Уважительное отношение слушателей института к Т.И. Вяземскому видим в телеграмме от 10.04.1914 г., отправленной А.Н. Ясинским на его московский адрес Ваганьковский переулок, 6: «Участники первого собрания слушателей института глубоко сожалея о вашем отсутствии приветствуют вас и желают скорейшего выздоровления. Ясинский» (Там же. Д. 145. Л. 1)

Идеи Т.И. Вяземского по борьбе с алкоголизмом порой отторгались не только в обществе, но и в медицинской среде, иногда воспринимались враждебно. Вопросы, связанные с мерами по регулированию продажи алкоголя большей частью общества, всегда воспринимались болезненно и негативно. Но это лишь подчеркивает необходимость принятия в государственном масштабе не запретительных, а пропедевтических (предупредительных) мер в борьбе с алкоголизмом, разработанных Т.И. Вяземским.

\section{Кавказские минеральные воды}

Т.И. Вяземский в период 1885-1903 гг. состоял действительным членом Русского бальнеологического Общества в Пятигорске (далее: РБО), принимал активное участие в его работе. В летние периоды приезжал на Кавказские минеральные воды, работал в Кисловодске, Пятигорске, Железноводске.

\section{К истории Кавказских минеральных вод}

В то время официальной датой открытия первого лечебного сезона считали 1798 г. и столетний юбилей приурочивали к маю 1898 г. (Святловский, 1898. С. 3). В работе министра земледелия и государственных имуществ России Алексея Сергеевича Ермолова (1847-1916) так же указано, что в 1898 г. истекает первое столетие Кавказских минеральных вод в качестве курорта ([Еромолов], 1898. С. 2). В Санкт-Петербурге в период с 12 по 16 декабря 1898 г. прошел Первый всероссийский съезд деятелей по климатологии, гидрологии и бальнеологии, приуроченный к 100-летию Кавказских минеральных вод (далее: Первый съезд бальнеологов). Торжественное открытие состоялось в здании городской Думы, а заседания проходили в здании Военно-медицинской академии (Дневник высочайше..., 1898. С. 2-3). В 1899 г. вышли Труды Первого съезда бальнеологов (Труды высочайше..., 1899).

Новая дата возникла, можно сказать, случайно. В 1898 г., во время лечебного сезона на Кавказских минеральных водах РБО поручило Т.И. Вяземскому составить библиографию вод с краткой аннотацией каждой печатной работы. «В виду обширности материала и краткости времени (двухмесячный срок), - пишет Т.И. Вяземский, - я не мог довести до конца начатого труда» (Дебаты по..., 1899. С. 540). Однако, побочным результатом работы, явилось исследование, посвященное столетию Кавказских минеральных вод. Отдельная, первая публикация «К вопросу о столетии Кавказских минеральных вод (посвящается памяти военного врача Петра Ивановича Шателовича)» вышла в марте 1899 г. (Вяземский, 1899). В работе аргументированно доказано, что столетний юбилей необходимо праздновать не в 1898 г., а в 1903 г. Исследование посвящено военному врачу П.И. Шателовичу, впервые в 1797 г. поставившему вопрос об устройстве лечебницы вблизи «кислых колодцев», а для безопасности лечения - построить «необходимое укрепление» (Там же. С. 3). Здесь важно подчеркнуть: «Из 
того факта, что вопрос о Кавказских минеральных водах поставлен не в центре, а возбужден в нем с периферии, следует в данном случае, что результаты научной экспедиции во главе с Палласом не повлияли на Медицинскую коллегию. Знаменитый труд Гюльденштедта вышел из печати в 1787 г., а Палласа в 1799-1801. Следовательно, за 10 лет до донесения Шателовича Медицинская коллегия знала или могла знать точно о существовании горячего серного источника, и за эти 10 лет она ничего не предпринимала». - Пишет Т.И. Вяземский (Там же. C. 3). Он подробно рассматривает факты забвения результатов прошлых исследований (Там же. C. 4-6) и делает вывод: «[...] мы видим, что Медицинская канцелярия имела уже описание Кавказских теплых и кислых вод. Кем, когда и при каких обстоятельствах оно составлено остается пока неизвестным, так как, к сожалению, самое описание вод не сохранилось при делах Медицинской канцелярии» (Там же. С. 6).

Парадоксально, но Медицинская коллегия ничего не предпринимала для обустройства вод, которые могли бы намного раньше вступить «на правильный путь своего развития». В такой ситуации только энергичная деятельность П.И. Шателовича побудила Медицинскую коллегию обратить внимание на воды. «Пусть хоть хорошее о нем воспоминание, - пишет Т.И. Вяземский, - со стороны многих теперешних врачей, так много обязанных в своей жизни настоящему состоянию Кавказских минеральных вод, послужит для него благодарностью со стороны потомства» (Там же. С. 3). К сожалению, роль П.И. Шателовича в должной мере в истории Кавказских минеральных вод не отражена.

Возникшую проблему о столетии Кавказских минеральных вод, отмеченном в 1898 г., рассмотрел доктор медицины, бальнеолог, профессор Московского университета Виктор Степанович Богословский (1841-1904) (Богословский, 1899). Он, в частности, указал, что этот вопрос предварительно не обсуждался среди ученых. Все были уверены, что на Первом съезде бальнеологов будут представлены документы о том, что 1798 г. является первым годом официального существования Кавказских минеральных вод. Но этого не случилось.

Отметим, что при открытии Первого съезда бальнеологов в своей приветственной речи председатель правления съезда профессор А.И. Лебедев ограничился голословным заявлением: «[...] время открытия съезда совпадает со столетием существования нашей старейшей и по своему благоустройству главнейшей лечебной станции, а именно Кавказских минеральных вод» (Труды Высочайше..., 1899. С. XV).

Вернемся к рассуждениям В.С. Богословского: «Как больно за наши знаменитые отечественные курорты, что такой важный факт, как столетнее их существование, обойден полным молчанием. Сто лет воды служат верой и правдой народному здравию, и этот старик юбиляр не получил себе даже приветствия [...] Больно за тех маститых деятелей, любовью и умом которых воды подвигались в их прогрессивном развитии, - больно, потому что им со стороны современников не отдана была на съезде дань благодарности. Непонятно, зачем тогда потребовалось приурочивать съезд к столетию вод, когда обсуждение исторического развития их даже и не вошло в программу съезда» (Богословский, 1899. С. 548-549).

Обсуждение в программу Первого съезда бальнеологов не вошло, а выступление Т.И. Вяземского было заявлено на 15 декабря 1898 г. (Труды высочайше..., 1899. С. ХІ). Однако, при отсутствии обсуждения этого вопроса, выступать Т.И. Вяземскому было нецелесообразно. В.С. Богословский выражает надежду, что исследования Т.И. Вяземского восполнят существующий пробел на следующем, Втором съезде бальнеологов: «[...] к счастью для вод, оказывается теперь (конечно, если только организаторы съезда не опровергнут доводов д[окто]ра Т.И. Вяземского), что столетний их юбилей наступит только через 4 года. Кавказские врачи тогда достойным образом отпразднуют этот праздник всероссийской лечебницы» (Богословский, 1899. С. 549).

Доводы Т.И. Вяземского никто не опроверг. Члены РБО после тщательного обсуждения в CXV заседании РБО 26 мая 1899 г. «единогласно приняли, что за первый год существования Кавказских мин[еральных] вод нужно признать не 1798 г., а 1803 г.» (Дебаты по..., 1889. С. 545). На указанном заседании Т.И. Вяземский поставил вопрос о тщательной подготовке к 1903 г. «Если мы не желаем и в будущем, - в 1903 г. - отпраздновать таким же образом, как это было в 
1898 г., то должны немедленно приступить к работам. - Замечает Т.И. Вяземский. - Работ много. Укажу на главные.

1. Необходима история вод за 100 лет. Для ее составления требуется архивный материал министерства внутренних и военных дел, а также архивный материал дирекции вод [...].

2. Необходима библиография Кавказских мин[еральных] вод. Она так обширна, что потребуется коллективная работа ряда лиц. Требуется не простой перечень названий работ, а изложение содержания каждой из них.

3. Биографический словарь деятелей и писателей.

4. Геологический очерк Пятигорского края [...].

5. Необходима обработка [...] метеорологического материала [...].

Я указываю на главные работы, - пишет Т.И. Вяземский, - которые безусловно необходимы. Кавказские минеральные воды заслужили подобное к себе отношение столетнею своею службою народному здравию» (Там же. 1889. С. 546-547) (рис. 3).

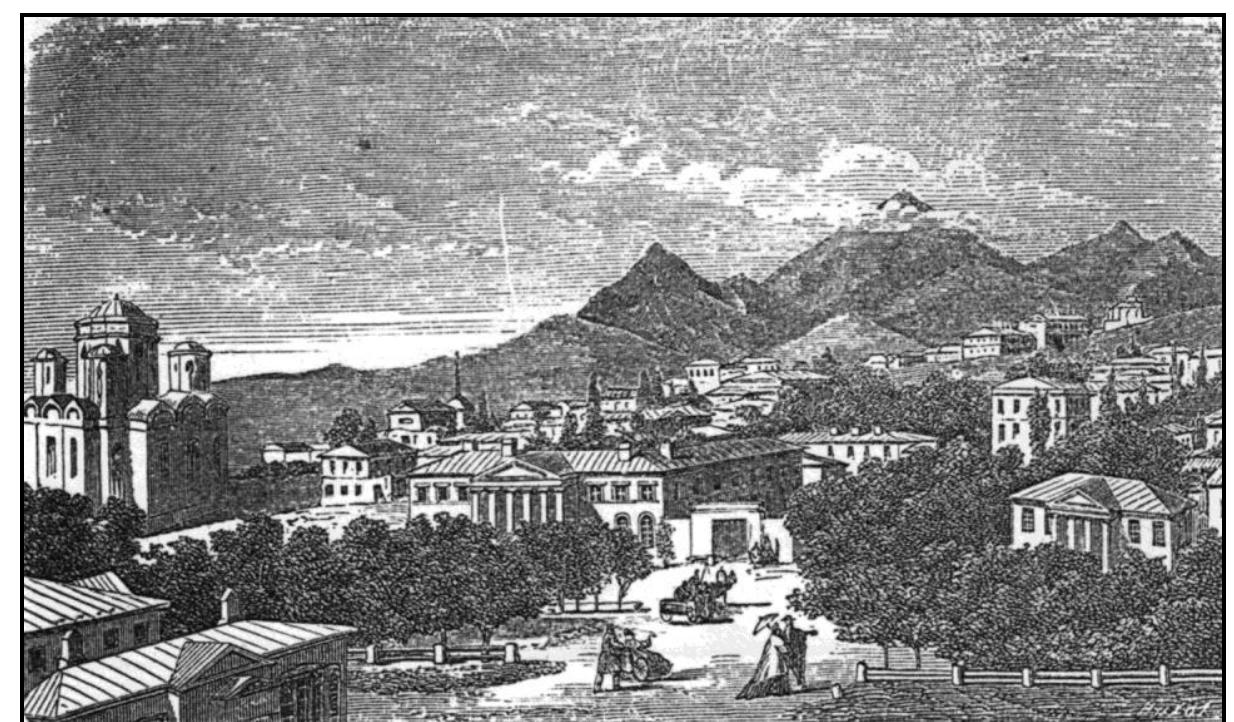

Рис. 3. Вид Пятигорска. Рисунок второй половины XIX в. из книги В.В. Святловского

(Святловский, 1898. С. 93)

Казалось бы, историческая справедливость восторжествовала - новая столетняя дата в истории вод будет связана с именем Т.И. Вяземского. В 1903 г. вторым изданием вышла его книга (Вяземский, 1903). Но обстоятельства стали складываться явно не в пользу Т.И. Вяземского. На Втором всероссийском съезде деятелей по климатологии, гидрологии и бальнеологии в память императора Петра Великого, проходившем в 1903 г. с 1 по 7 сентября в Пятигорске в столетнюю годовщину начала устройства Кавказских минеральных вод (далее: Второй съезд бальнеологов), Т.И. Вяземский не присутствовал, а в официальных материалах съезда его имя не указано. После Второго съезда бальнеологов в 1904 г. вышла книга «Кавказские минеральные воды. Пятигорск. Железноводск. Ессентуки. Кисловодск. К столетнему юбилею 1803-1903 г.» (Кавказские минеральные..., 1904) в роскошном издании на мелованной бумаге в темно-зеленом переплете с изображением символа Кавказа - орла на фоне темно-золотого неба. Автор книги не указан. Из предисловия, подписанного составителем, пожелавшим остаться неизвестным, узнаем любопытные факты: «24-го апреля 1903 года исполнилось столетие существования Кавказских минеральных вод - событие, которое заслуживало быть особо отмеченным. Ввиду этого г[осподину] министру земледелия и государственных имуществ А.С. Ермолову угодно было поручить мне озаботиться составлением очерка как исторического развития, так и современного состояния этих богатейших курортов, применяясь к требованиям большой публики, и, следовательно, устраняя весь излишне громоздкий материал, имеющий значение лишь для специалистов. При исполнении возложенной на меня задачи я руководствовался, помимо собственных наблюдений и опросов сведущих лиц, еще нижеследующими сочинениями [...]» (Там же. С. [1]). 
Неизвестный составитель перечисляет семь авторов, среди которых книга Т.И. Вяземского не указана. На первом месте находится книга А.С. Ермолова «К вопросу о переустройстве Кавказских минеральных вод в связи с общим положением бальнеологического дела в России и за границею. Записка министра земледелия и государственных имуществ» ([Ермолов],1898). Интересно отметить, что министр в своей книге пишет: «[...] ныне истекает первое столетие существования Кавказских минеральных вод, как лечебного курорта [...] (Там же. С. 2). Отметим, что автор книги А.С. Ермолов на титульном листе не указан. Только для сведущего читателя будет понятно, что за словами на титуле книги: «Записка министра земледелия и государственных имуществ» стоит господин А.С. Ермолов.

Неизвестный составитель, мудрствуя лукаво, в своей книге дает цитату из книги А.С. Ермолова: «[Кавказские минеральные воды] в течение векового своего служения больному человечеству [...] приобрели себе широкую известность не только в России, но и за границею, и представляют собою ценное государственное достояние [...]. (Кавказские минеральные..., 1904. С. 295) и ([Ермолов], 1898. С. 2). То есть, речь идет об информации, подготовленной к столетнему юбилею Кавказских минеральных вод, празднование которого состоялось в 1898 г. и автоматически, без каких-либо оговорок, использованной на втором столетнем юбилее, год которого определил Т.И. Вяземский. О Т.И. Вяземском не сказано ни слова, как бы и не было никакого исследования по поводу празднования столетнего юбилея вод в 1903 г.

Не станем расставлять акценты в этой запутанной и неприятной истории, тем более, что необходимы дополнительные исследования, касающиеся истории РБО и его взаимоотношений с администрацией вод. Положительным фактором является то, что книга неизвестного составителя подтвердила тот столетний юбилей вод, на который указал Т.И. Вяземский. При этом имя исследователя обойдено молчанием. Если одна из задач составителя была в том, чтобы вычеркнуть из истории Кавказских минеральных вод имя Т.И. Вяземского, то он прекрасно с ней справился. Ни в справочниках, ни в публикациях по Кавказским минеральным водам, вплоть до сегодняшнего дня, когда речь заходит о том, что начало курорта относится к 1803 г. и соответствующие юбилеи необходимо соотносить с этим годом, мы не встретим имя Т.И. Вяземского, определившего этот важный факт. Приведем пример.

В 2003 г. отметили 200-летие Кавказских минеральных вод. К этой дате Всероссийское общество охраны памятников истории и культуры выпустило альманах «Памятники Отечества» № 49 (Кавказские минеральные..., 2001). В альманахе помещены материалы, повествующие о богатой истории и культуре Кавказских минеральных вод. В сокращенном варианте представлены выдержки из книги вышеупомянутого неизвестного составителя (Кавказские минеральные...,1904) - в альманахе они скомпонованы под названием: «100 лет Кавказским минеральным водам» (Кавказские минеральные..., 2001. С. 16-33). Книга эта, как мы знаем, ничего не говорит о том, кто открыл юбилейную дату Кавказских минеральных вод. Нет упоминания о Т.И. Вяземском и в других публикациях альманаха.

Выразим надежду, что наше короткое путешествие в прошлое, поможет восстановить историческую справедливость и в скором времени имя Т.И. Вяземского займет свое, утраченное волей обстоятельств, достойное место в истории Кавказских минеральных вод.

\section{Исследования по электротерапии}

На страницах «Протоколов» и «Записок» РБО Т.И. Вяземским опубликовано 12 научных работ на различные темы, большая часть из них посвящена вопросам электротерапии.

Первая работа «О желательном устройстве водяных электрических ванн в Кисловодске» была представлена на заседании РБО 28.07.1885 г. (Вяземский, 1885). В ней мы видим исследователя, который склонен критически оценивать и совершенствовать электротерапевтическое воздействие на больного при приеме ванн. В бальнеологических исследованиях Т.И. Вяземского красной нитью проходит прежде всего забота о человеке. В начале статьи читаем: «Наши образованные классы с их несоразмерными умственными занятиями и наши промышленные центры с их тревожными коммерческими сделками доставляют в Кисловодск массу нейростеников, что отнюдь не должно показаться лишним их желание поставить в ряд других физических методов лечения и методы электризации» (Там же. С. 36-37). 
С чрезвычайной тщательностью Т.И. Вяземский подошел к изучению распределения токов при применении водяных диполярных ванн. На заседании РБО, состоявшегося 29.08.1887 г., был зачитан доклад Т.И. Вяземского (Вяземский, 1887) по данному вопросу (по ряду причин он не смог присутствовать на заседании). В докладе был рассмотрен вопрос о силе тока, проходящего через тело человека, принимающего диполярные водяные ванны. Результаты работы не вполне удовлетворили Т.И. Вяземского, и он планирует провести дополнительные исследования: «[...] этим не оканчиваются все те выводы, которые можно извлечь из представленного материала и которые должны лечь в основу рассуждения по вопросу о более целесообразном устройстве ванн с электротехнической точки зрения. Это в связи с полным изложением вычислений электрических величин послужит предметом следующего сообщения» (Там же. С. 25).

Следующее сообщение о диполярных ваннах последовало почти через год - 9 июня 1888 г. (Вяземский, 1888 а.). Т.И. Вяземский присутствовал на заседании РБО и в своем докладе аргументированно доказал возможность дозирования тока в зависимости от состояния больного: «[...] величина силы тока, идущего через человеческое тело, определяется из разности величин сил тока до и после погружения тела в ванну. Раз это так, то дается легкая возможность дозировать ток согласно требованиям того или другого случая» (Там же. С. 12).

Т.И. Вяземский продолжает исследования и в следующем, 1889 г., до отъезда в научную командировку в Германию. В заседании РБО от 10.07.1889 г. делает доклад «Об электрических явлениях, обнаруживающихся при применении Кавказских минеральных ванн» (Вяземский, 1889). Собственные тщательные опыты Т.И. Вяземского позволили определить противоречия в исследованиях западноевропейских ученых.

Данная проблема продолжала волновать Т.И. Вяземского. В 1890 г., пребывая в Германии в научной командировке (1889-1891 гг.), он вновь подвергает критическому анализу свои данные. Пишет несколько статей и посылает в Россию, где они были зачитаны в заседаниях РБО. В одной из них, зачитанной на заседании РБО 17.08.1890 г. (Вяземский, 1890), он обращает внимание, что для приема диполярных ванн необходимы сведения по электричеству: «Предписать диполярную ванну также легко, как и кисловодский воздух, но для ее осуществления со стороны выполнителя требуются точные физические сведения по электричеству» (Там же. С. 2). Делает итог своим исследованиям: «Общее правило для клинициста будет то, что разница между силою тока до и после погружения тела определяет собою это количество электричества, которое получает больной» (Там же. С. 25).

Председатель РБО Семен Алексеевич Смирнов (1819-1911) в экстраординарном заседании РБО от 3 сентября 1890 г., целиком посвященному работам Т.И. Вяземского об электрических явлениях в минеральных источниках, подчеркнул, что эти исследования были вызваны по инициативе и поддержке РБО и дает им высокую оценку: «Основанные на ряде многочисленных исследований при помощи самых чувствительных инструментов, взгляды автора чужды увлечения. Добросовестность и объективность, которые он обнаружил в изучении столь тонкой стороны интересующей нас области, вполне заслуживают нашего одобрения» (XLVII экстраординарное..., 1890. С. 3).

В отечественной и зарубежной бальнеологии продолжали доминировать взгляды о том, что терапевтический эффект при лечебном использовании минеральных вод достигается путем электрических свойств воды. Это положение было сформировано в середине XIX века французским ученым, хирургом Скуттетеном Робертом Иосифом Генри (1799-1870) (у Т.И. Вяземского: Скутетен). Т.И. Вяземский публикует в 1895 г. статью по критической оценке данных Скуттетена в первом номере журнала «Минеральные воды» (Вяземский, 1895). Журнал был посвящен успехам бальнеологии, гидротерапии и климатотерапии, выходил в Пятигорске под редакцией В.С. Богословского и Т.И. Вяземского. Статья написана живым, понятным языком с привлечением собственных экспериментальных данных и умозаключений, указывающих на несостоятельность теории Скуттетена: «[...] поместим ли человеческое тело в такую минеральную ванну, с которой оно дает малую величину разности потенциалов, или в такую, с которой оно даст значительную величину, все равно токов наблюдаться не будет. 
Будет только разность потенциалов в плоскости соприкосновения, и нужна внешняя часть иепи от тела и воды, чтобы был ток.

Отсюда вся теория Скутетена о механизме целебного действия минеральных вод на организм является лично для меня совершенно несостоятельною», - пишет Т.И. Вяземский (Там же. С.13).

В заседании РБО 5 августа 1898 г. Т.И. Вяземский представил свою новую работу «Земные электрические токи (по поводу изучения влияния серных терм на организм)» (1898/1899). В работе суммированы исследования зарубежных и отечественных ученых. В целом, с существованием земных электрических токов «нужно считаться и бальнеологам», пишет Т.И. Вяземский (Там же. С. 5). Он говорит о собственных кратковременных опытах, проводимых в районе Провала (рис. 4). Также ставит вопрос о необходимости изучения земных токов в районе горы Машук.

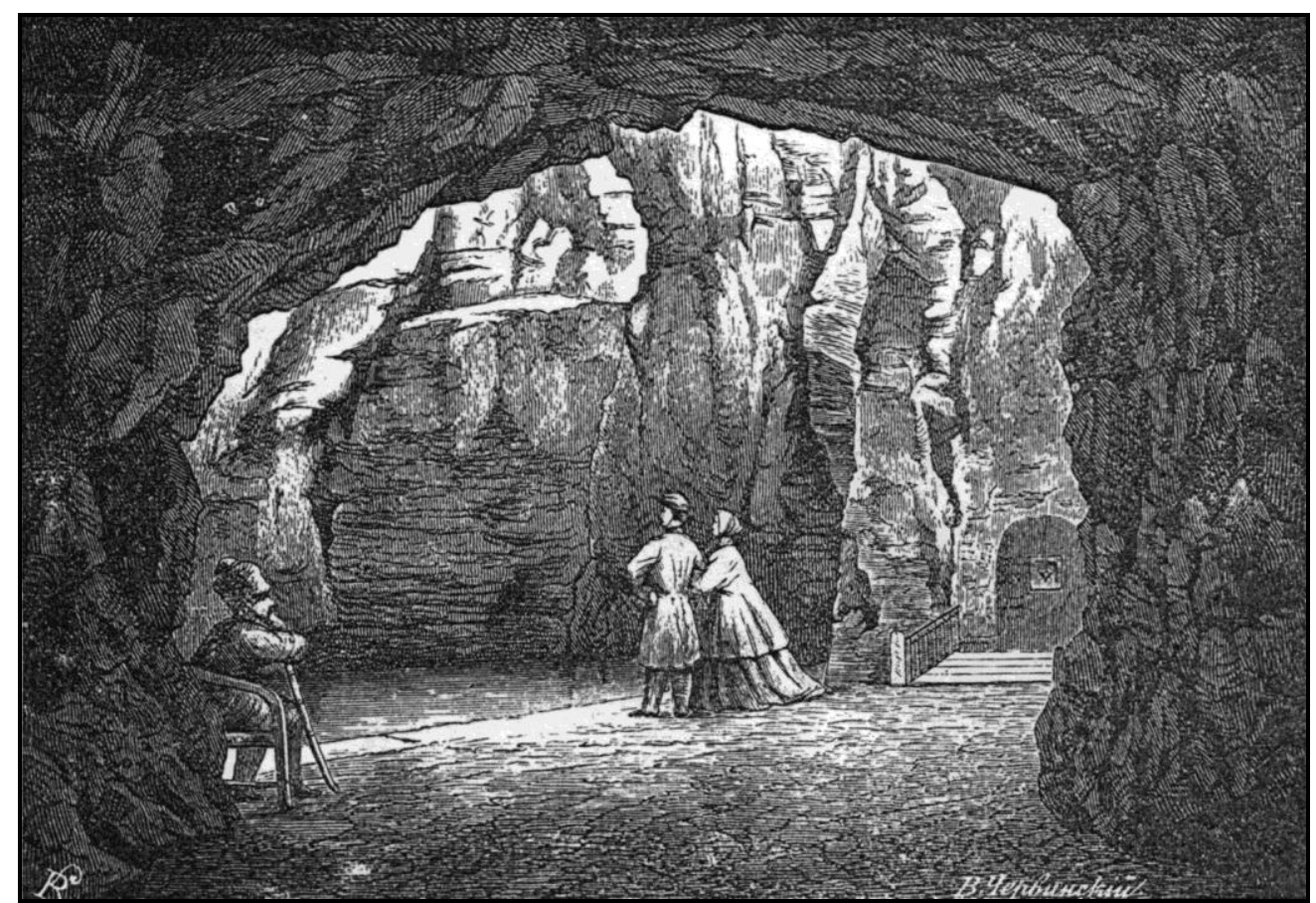

Рис. 4. Большой Провал вблизи Пятигорска. Рисунок второй половины XIX в. из книги В.В. Святловского (Святловский, 1898. С. 73)

Подведем некоторый итог работ Т.И. Вяземского по изучению электричества в воде минеральных источников. Для этого обратимся к компетентному мнению В.С. Богословского, отметившего, что в результате опытного изучения минеральных источников, Т.И. Вяземский показал, «что в воде минеральных источников не циркулирует ток. Все, что можно констатировать - это существование электрической разницы, вызываемой соприкосновением тела с водою. Работы Т.И. Вяземского пока единственные в русской бальнеологической литературе, а по той опытной постановке, при которой они проводились, и единственные в европейской литературе», - пишет В.С. Богословский (ЦИАМ. Ф. 418. Оп. 408. Д. 112. Л. 3). Уточним, что Т.И. Вяземский доказал несостоятельность распространенной среди отечественных и зарубежных бальнеологов теории о том, что в минеральной воде циркулирует ток.

Несложно заметить, что область электротерапии - одно из приоритетных направлений в сфере научных интересов Т.И. Вяземского. Начав изучение электрических явлений в воде минеральных источников и земле, он продолжал проводить собственные опыты на растениях. В сентябре 1901 г. на медицинском факультете Московского университета успешно защитил диссертацию «Электрические явления растений» (Вяземский, 1901). Работа Т.И. Вяземского не утратила своего значения и в наши дни. Ее подробное рассмотрение целесообразно представить в отдельной статье.

Труды Карадагской научной станции им. Т.И. Вяземского - природного заповедника РАН. - 2016. - Вып. 1 
Кавказские минеральные воды - это яркий период в жизни Т.И. Вяземского. Нами рассмотрены лишь отдельные эпизоды, в которых Т.И. Вяземский выступает в качестве ученого-бальнеолога и исследователя истории Кавказских минеральных вод.

С покупкой в 1901 г. в Восточном Крыму имения «Карадаг», сфера его интересов направлена в Крым, куда он перевозит свою обширную библиотеку, а затем строит научную станцию.

\section{Карадагская научная станция и библиотека}

\section{К истории библиотеки}

Главным богатством, которым обладал Т.И. Вяземский, были книги. Начало собирательства относится к его студенческим годам на медицинском факультете Московского университета (рис. 5). Во время учебы в университете (1878-1883) у Т.И. Вяземского формируется убеждение в том, что в основе общества должна находиться культура. В одной из записных книжек, относящейся к периоду учебы на старших курсах, находим сделанный рукой Т.И. Вяземского набросок схемы в виде эллипса, где в пересечении осей симметрии находится культура, а в точках пересечения эллипса с осями симметрии (вершины) вписаны производные культуры: этика, эстетика, история, знание, наука, техника... (ЦИАМ. Ф. 1336. Оп. 1. Д. 5. Л. 37). Условно назовем схему Т.И. Вяземского культурно-центристской моделью общества. Размышления о месте культуры в обществе определили основное убеждение Т.И. Вяземского в том, «[...] что впереди всего должно быть научное знание, что только на этом фундаменте может быть основано человеческое общежитие [...]» (Крым, 1917. С. 14).

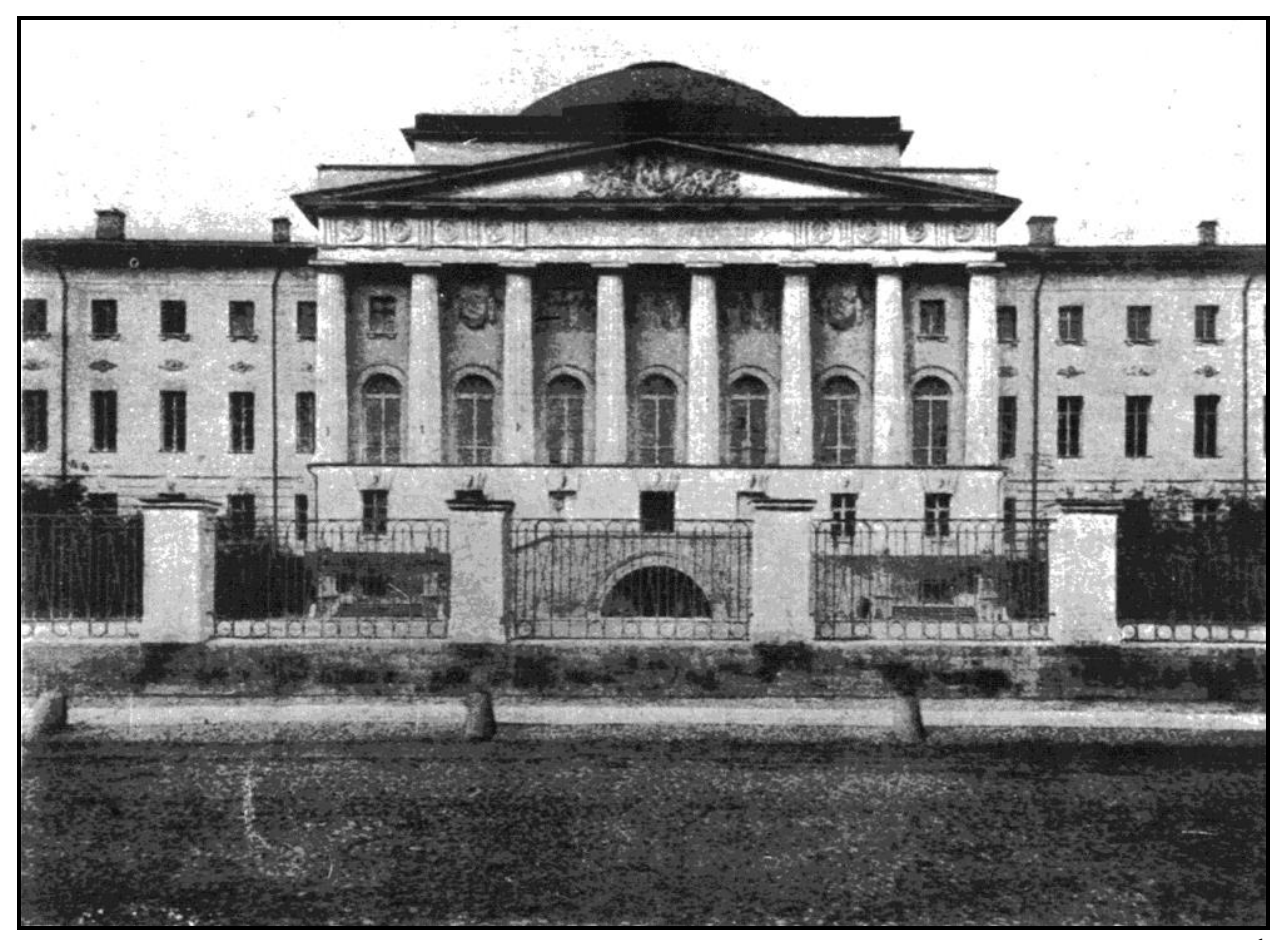

Рис. 5. Главное здание Московского университета на Моховой улице. Фотография 1884 г.

Во многом, ради культурного обустройства общества Т.И. Вяземский стал собирать книги. Ему удалось собрать библиотеку более чем в 30000 томов по многим отраслям естествознания. В этом он наследовал традицию русских библиофилов XVIII века, стремившихся иметь книги по всем отраслям знания.

Книжный знак Т.И. Вяземского с изображением двух Фаустов и ангела с раскрытой книгой помещен в первой монографии о русском книжном знаке В.А. Верещагина (Верещагин, 1902. Рис. 72). Этот сюжетно-тематический книжный знак, а также штемпельные книжные знаки и суперэкслибрисы Т.И. Вяземского рассмотрены в нашей работе (Михаленок, Лапченко, 2012). 
Обладателями крупных частных коллекций были состоятельные люди, в основном из дворянской интеллигенции, а в середине XIX века ряды библиофилов пополнили купцы, промышленники, ученые. Т.И. Вяземский не был обладателем крупных капиталов, но не был он и бессребреником. Геолог, заведующий (директор) Карадагской научной станцией им. Т.И. Вяземского в 1914-1927 гг. Александр Федорович Слудский (1884-1954) отметил: «[...] он [Т.И. Вяземский] был хорошо известен в Москве, как талантливый невропатолог и психиатр, много практиковал на Кавказе, на Минеральных водах [...]» (Слудский, 1917 1а. С. 5). «У него была большая практика в самых аристократических московских семьях и среди купечества», пишет товарищ Т.И. Вяземского Н.П. Розанов (Розанов, 1914. С. 7). Не ошибемся в том, что врачебная практика приносила Т.И. Вяземскому достаточно средств для приобретения книг.

Тем не менее, оставался открытым вопрос о том, при каких обстоятельствах у Т.И. Вяземского возник интерес к библиофильству. Возможный ответ был обнаружен в публикации М.М. Калмыковой (Калмыкова, 2013) о книгах Т.И. Вяземского, переданных в библиотеку Симферопольского педагогического института. В наше время книги хранятся в научной библиотеке Крымского федерального университета им. В.И. Вернадского. На одной из книг, принадлежавших Т.И. Вяземскому, сохранился штамп прежнего владельца - известного библиофила и библиографа Павла Васильевича Щапова (1848-1888) (Там же. С.180). Кроме того, М.М. Калмыкова упоминает о том, что П.В. Щапов скончался на руках Т.И. Вяземского и дает ссылку на публикацию известного филолога-палеографа, книговеда, библиографа Павла Константиновича Симони (1859-1939) о П.В. Щапове в редком, малодоступном издании (Симони, 1929).

Познакомимся с публикацией подробнее. П.К. Симони пишет о П.В. Щапове как об одном «из известных и наиболее заслуживающих воспоминания библиофилов-москвичей [...]» (Там же. С. 237). Характеризует его как «неутомимого собирателя и глубокого знатока - библиографа нашей старопечатной старины, а равно и книг новой печати вплоть до 60-ых гг. XIX века» (Там же. С. 237). Дает некоторые биографические сведения. Родился П.В. Щапов в богатой купеческой семье. Отец был старообрядцем. После хорошей домашней подготовки П.В. Щапов вольнослушателем окончил историко-филологический факультет Московского университета. Благотворное влияние на П.В. Щапова оказали выдающиеся библиофилы - Николай Саввич Тихонравов (1832-1893) историк литературы, археограф, профессор, а с 1877 г. ректор Московского университета, собиратель и исследователь древних и старообрядческих рукописей; граф Алексей Сергеевич Уваров (1825-1884) - ученый, археолог, один из основателей Исторического музея в Москве, владелец одной из лучших частных библиотек в 100000 томов; известный историк-археолог Михаил Петрович Погодин (1800-1875), который собирал книги, иконографические материалы, предметы истории и искусства. Под влиянием такого знакомства у П.В. Щапова «сложился его собирательский вкус и книжный культ» (Там же. С. 238).

Щапов был богатым человеком, поэтому предложения о покупках книг поступали к нему постоянно. Он так же любил заходить в лавки книжных торговцев и антикваров, а по воскресеньям навещал Сухаревку. Он очень тщательно отбирал книги, стремился, чтобы из нескольких экземпляров у него оставался лучший. «Его библиотека, - пишет П.К. Симони, - сказочно росла не по дням, а по часам [...] Для библиотечной работы над книгами у Щапова было три кабинета, причем книги переходили по мере изучения и сравнения из одного кабинета в другой, как бы души, странствуя, попадали в Чистилище, так и книги - пока попадут на постоянное место на его библиотечной полке [...] Щапов скончался 6-го июля 1888 г. в своем книжном Эдеме посреди своих собраний книг, на руках любимой женщины-друга и доктора Т.И. Вяземского, тогда еще студента старшего курса, тоже библиофила и ныне тоже покойного» (Там же. С. 241).

Здесь П.К. Симони ошибается, в 1888 г. Т.И. Вяземский был врачом (медицинский факультет он окончил в 1883 г.). Летом 1888 г. в качестве практикующего врача он находился на Кавказских минеральных водах. Узнав о болезни своего друга и пациента, приехал в Москву. Затем, после похорон, вновь вернулся на воды. В заседании РБО 16 июля был заслушан его доклад «Локализованные поражения коры головного мозга» (Вяземский, 1888). Это подчеркивает достаточно близкие, доверительные, дружеские отношения между П.В. Щаповым и Т.И. Вяземским. 
Мы полагаем, что основное ядро коллекции Т.И. Вяземского (до 10000 книг) сформировалось под влиянием П.В. Щапова довольно быстро - в течении пяти лет после завершения учебы в Московском университете. Он приобретал за невысокую плату те экземпляры книг, которые по тем или иным причинам не подошли П.В. Щапову, но имели безусловную ценность. Кроме того, в совместных походах по книжным местам Москвы Т.И. Вяземский, приобретая книгу, прислушивался к советам своего товарища. Часть книг могла быть подарена П.В. Щаповым Т.И. Вяземскому. Собирательский вкус Т.И. Вяземского сформировался под влиянием П.В. Щапова.

К началу XX века в количественном составе библиотека Т.И. Вяземского сравнялась с библиотекой П.В. Щапова: в обеих библиотеках было около 30000 томов. Обе библиотеки представляют культурную, научную ценность и вряд ли уместно сравнение - какая более ценна. По завещанию, после смерти П.В. Щапова, его книги поступили в Московский исторический музей.

Судьба библиотеки Т.И. Вяземского не столь удачна. Приведем пример о передаче книг в другие организации Крыма. В 1940 г. вышла работа Р.И. Белкина (Белкин, 1940), посвященная 25-летию существования Карадагской биологической станции. Автор сообщает, что первоначально библиотека насчитывала 50 тысяч корешков, из которых 15 тысяч было передано [вторая половина 1930-х гг.] крымским медицинскому и педагогическому институтам (Там же. C. 162). Книги эти, частично, сохранены до настоящего времени. В дальнейшем, к сожалению, передача «непрофильных» для биологической станции книг стала печальной закономерностью. Так, в 1960-х гг. более 300 ценных книг были переданы соответственно профилю организаций: медицинская литература поступила в библиотеку Крымской областной психиатрической клинической больницы и в Крымскую областную научно-медицинскую библиотеку, а литература по различным направлениям сельского хозяйства - в библиотеку винного совхоза «Коктебель» (Михаленок, Лапченко, 2012).

Сотрудники Государственной исторической публичной библиотеки (далее: ГПИБ) проводят реконструкцию библиотеки П.В. Щапова (Воробьева, Шицкова, 2009). Материалы публикации, при сравнении с нашими исследованиями, позволяют сделать некоторые выводы о схожести библиотек П.В. Щапова и Т.И. Вяземского. Отметим основные моменты.

Значительное количество книг в библиотеке П.В. Щапова происходит из других книжных собраний, выявлено 533 прежних владельца (Там же. С. 150), что характерно и для библиотеки Т.И. Вяземского. По нашей предварительной оценке, в общей сложности, в библиотеке Карадагской научной станции им. Т.И. Вяземского, а также в библиотеках научных и учебных организаций Симферополя, где хранятся книги Т.И. Вяземского, нами выявлено более 100 прежних владельцев библиотек.

Характерной чертой комплектования коллекции П.В. Щапова была покупка книг в букинистических магазинах (Там же. С. 150). Эту особенность мы видим и у Т.И. Вяземского. В коллекции его книг имеются книгопродавческие ярлыки следующих магазинов: Книжный магазин Н.П. Карбасникова в Москве, Книжный магазин П.Ф. Яковлева в Москве, Книжный магазин В.И. Клочкова в Петербурге, Книжный магазин Киммеля в Риге, Книжный магазин С.И. Гомолинского в Киеве и др. (Лапченко, Михаленок, 2004. С. 50).

Существуют и другие, общие признаки, характерные для обеих библиотек. Исследования в этом направлении целесообразно провести общими усилиями сотрудников Карадагской научной станции им. Т.И. Вяземского и ГПИБ.

Частная коллекция доктора медицины Т.И. Вяземского - это воплощение мечты о науке и просвещении народных масс, которую он стремился достичь путем собирательства книг по многим направлениям естествознания, а затем строительства Карадагской научной станции, для деятельности которой и была предназначена библиотека. Некоторые сведения об этой мечте узнаем из рукописной работы А.Ф. Слудского «Карадагская научная станция (исторические очерки)» (Слудский, [1934-1935]).

«Фундамент будущего счастья народов, - пишет А.Ф. Слудский, - счастья человечества должен быть основан на твердой почве точного знания, точной науки - такова основная идея, с 
которой Вяземский начал свою сознательную жизнь, и которая красной нитью прошла через всю его деятельность. Эта идея была для него основным критерием познания добра и зла. Все, что способствует развитию и процветанию науки - хорошо, все, что препятствует движению науки - плохо. Точное наблюдение, удачно поставленный эксперимент, раскрывающий законы природы, блестящий обобщающий вывод, позволяющий глубже заглянуть в сложную лабораторию живого организма - вот те величайшие ценности, которые глубоко захватывали и волновали Вяземского. А главным источником этих ценностей была книга. Со свойственным ему энтузиазмом, с лихорадочной жаждой узнать, что было сделано в различных областях естествознания и медицины представителями науки предыдущих поколений, Вяземский начал собирать книги и, постепенно втянувшись в это дело, стал ярым библиофилом. Однако он не стал коллекционером книг, одним из тех коллекционеров, для которых ценно не содержание книги, а ее древность.

Собирая свою замечательную библиотеку, Вяземский с первых шагов ставил себе определенную цель: он смотрел на свое собрание книг не как на свою личную собственность, а как на общенародное достояние, он искал тех путей, на которых его книжные богатства могли бы быть использованы наиболее широко и плодотворно, мечтал о том, чтобы книга была доступна каждому ищущему знания, независимо от состояния, сословия, рода занятий... Станция, создаваемая вдали от курортных местностей, должна была гостеприимно встречать всех, кто желает и может работать над исследованиями явлений природы вообще, и в частности в области биологических наук. Понятно, что библиотека должна была занять свое достойное место именно на этой станции. Но для этого предстояло найти подходящее место и выстроить станцию» (Там же. С. 3-4).

С 1901 г. Т.И. Вяземский с семьей ежегодно на летнее время приезжал в свое имение «Карадаг». Его жена - потомственная дворянка Надежда Григорьевна Вяземская (девичья фамилия - Вельтищева, по первому мужу - Евреинова). Отец Н.Г. Вяземской - Григорий Иванович Вельтищев был состоятельным человеком, ему принадлежали несколько домов и земельные участки по Большой Никитской улице и Брюсовому переулку в Москве. Взаимная любовь стала основой брака Терентия Ивановича и Надежды Григорьевны. Венчание состоялось 28 апреля 1899 г. в Никольском храме села Сасыкино Спасского уезда Рязанской губернии. Жениху исполнилось 42 года, невесте - 28 лет (ЦИАМ. Ф. 1336. Оп. 1. Д. 63. Л. 11 об). Уже после, в 1910-е годы, что-то порвется в отношениях, причинив обоюдную боль и отчуждение.

В природе Карадага Т.И. Вяземский увидел ее главную особенность: здесь у морских берегов и среди сказочных скал древнего вулкана, в наибольшей мере, по сравнению с другими местами природы, проявляется творческий союз природы и человека. В этом союзе главное место, как считал Т.И. Вяземский, отведено науке. Для строительства станции, таким образом, нашлось подходящее место, где могла бы быть реализована его мечта о царстве науки. Впрочем, многие современники считали его затею утопичной. Виднейшие деятели русской науки и литературы, отметил А.Ф. Слудский, говорили, что «вся идея Карадагской научной станции в корне своем утопия, что России не нужны подобные учреждения» (Архив КБС. Оп. 1. Д. 3 а. Л. 13).

В 1905 г. в имение на несколько дней заехал из Феодосии товарищ Т.И. Вяземского, доктор медицины, известный физиолог, профессор Московского университета Лев Захарович Мороховец (1848 - около 1919). В летнее время 1905 г. он жил в Феодосии. Приехав впервые на Карадаг, был очарован красотой местности. От Т.И. Вяземского узнал о намерении построить научную станцию. Эта идея увлекла Л.З. Мороховца, он не только поддержал ее, но и предложил помощь. В письме, отправленном Т.И. Вяземскому из Феодосии 25 июня 1905 г., он пишет: «Очарованный я возвращался от Вас. Ваше любезное гостеприимство и чудная местность Ваших владений никогда не изгладятся у меня из памяти и сердца!

О поразительных картинах и Вашем предприятии я уже писал в Москву своим друзьям [...]» (ЦИАМ. Ф. 1336. Оп. 1. Д. 99. Л. 1-2 об.). 
Через несколько лет, в 1907 г., обсудив план уже общего предприятия, Т.И. Вяземский и Л.З. Мороховец приступят к строительству научной станции. Пока вернемся к имению и библиотеке.

В имении Т.И. Вяземский организовал санаторий для нервнобольных людей. К нему приезжали на лечение люди из разных городов России. Лечил так же и местное население: «[...] слава о докторе Вяземском так широко разнеслась среди татарского населения, что к нему приезжали лечиться не только из разных деревень Крыма, но и с берегов Анатолии», - пишет А.Ф. Слудский (Слудский, 1917. С. 5-6).

Постепенно Т.И. Вяземский перевозил книги из Москвы в Крым. Большая часть книг к 1903 г. находилась в его имении. Книги были размещены в специальной библиотечной комнате (рис. 6), в кабинете, а часть, за отсутствием свободных комнат, хранилась в ящиках в подсобных помещениях. Известный библиограф, собиратель и исследователь книжных знаков Удо Георгиевич Иваск (1878-1922) в 1905 г. в одной из своих работ отметил: «Библиотека Т.И. Вяземского помещается в Крыму, в его имении Карадаге при Отузской долине, и заключает в себе больше 30000 томов. Преобладающий отдел - книги и периодические издания отечественной и иностранной академий наук, труды ученых обществ и журналы по физике, химии, естествознанию, медицине, антропологии и археологии; журналы Министерств народного просвещения и внутренних дел; монографии и диссертации» (Иваск, 1905. С. 100).

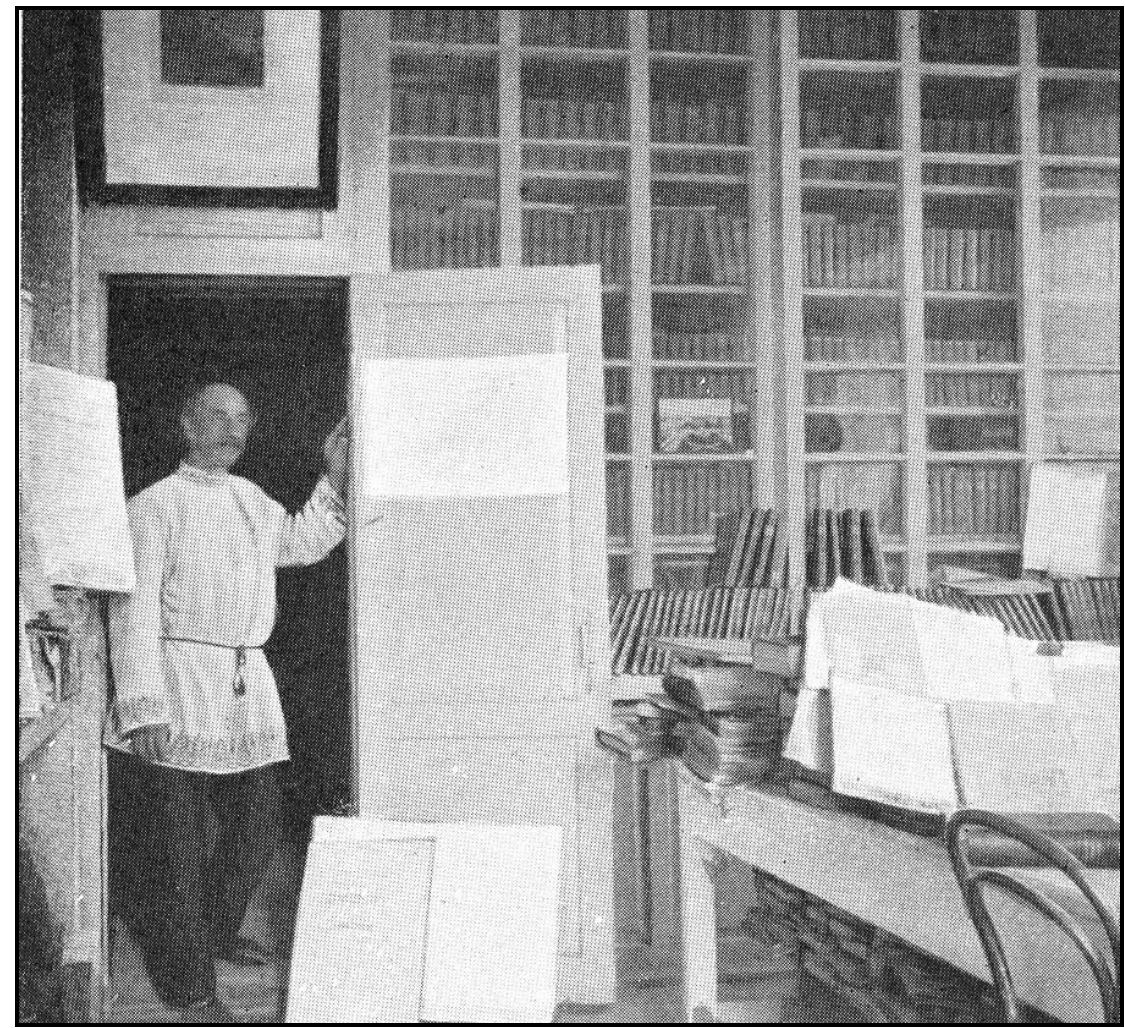

Рис. 6. Т.И. Вяземский в рабочей комнате библиотеки. Фотография 1910 [?] г. из статьи А.Ф. Слудского (Слудский, 1913. Рис. 5)

В тихом уединенном прекрасном уголке Восточного Крыма Т.И. Вяземский приступил к разборке книг и составлению каталога библиотеки. «Как здесь хорошо! Солнце, розы, тишина. Редко посылаю за газетами. - В июне 1906 г. писал Т.И. Вяземский в Москву, своему товарищу, историку Виктору Ильичу Чернопятову (1857-1935). - Занят исключительно разборкой библиотеки и раздумьем по поводу непрочности всего тленного. Нет ли у Вас записок Лопухина? Интересно их иметь.

Когда двинусь отсюда - не знаю. Хотелось кончить дело с библиотекой. Днем разбираю, вечером и ночью пишу каталог. Переписал уже около 1000 книг. Много крайне интересных. Редко кто меня посещает. Общество мое - это книги» (Чернопятов, 1914. С. 381). 
Т.И. Вяземский создает свой книжный Рай на Карадаге. Вокруг библиотеки возникает культурная среда. Посетители имения восторгаются богатством библиотеки. Послушаем современников Т.И. Вяземского, которые знакомились с библиотекой в имении «Карадаг».

Летом 1910 г. преподаватель Московского археологического института Н.И. Новосадский привез в Восточный Крым слушателей института для ознакомления их с археологическими объектами. В организации поездки и различных экскурсий деятельное содействие оказал преподаватель института, палеограф, член Общества им. Х.С. Леденцова, генерал-лейтенант Никандр Александрович Маркс (1861-1921), имение которого находилось вблизи Карадага, в деревне Отузы. Экскурсанты посетили имение Т.И. Вяземского, осмотрели его библиотеку: «27 июля, - пишет Н.И. Новосадский, - мы осматривали, благодаря любезности приват-доцента Московского университета Т.И. Вяземского, его богатую библиотеку, находящуюся на его даче вблизи Карадага. Эта библиотека состоит из книг, относящихся главным образом к области археологии, этнографии, флоры и фауны южной России. Тут экскурсанты познакомились с редкими изданиями А.Б. Ашика, графа А.С. Уварова, с полным собранием изданий Одесского Общества истории и древностей, со снимком карты Птолемея из одной итальянской рукописи XIII века и со многими другими библиографическими редкостями» (Новосадский, 1910. С. 8).

Краткое сообщение дает нам сведения о составе библиотеки. Добавим, что в библиотеке были так же широко представлены книги по медицине, геологии, географии, экономике, сельскому хозяйству и другим направлениям науки.

Товарищ Т.И. Вяземского, писатель, доктор медицины Сергей Яковлевич Елпатьевский (1854-1933) в период 1909-1913 гг. часто бывал у Т.И. Вяземского. Он хорошо знал состав библиотеки и использовал книги для своей работы. Библиотеку и станцию он назвал удивительной сказкой. В библиотеке, отметил писатель, «есть издания, которые разыскивались Т.И. Вяземским у букинистов по всей Европе; есть издания, стоящие 20 тыс. франков, - одно издание. [...] есть издания, которые имеются только во флорентийской публичной библиотеке, и вот тут, в нижнем этаже затерявшейся на Карадаге и никому не известной санатории» (Елпатьевский, 1998. С. 77).

Уточним, что Т.И. Вяземский во время заграничной командировки в Германии продолжал собирать книги, наладил связи с букинистами различных европейских стран. Однако, указывая на стоимость одного издания в 20 тысяч франков, С.Я. Елпатьевский, возможно, ошибается. Это непомерно огромная сумма. Инкунамбулы (книги, изданные с 40-х гг. XV в. по 1 января 1501 г.) можно было приобрести за несколько тысяч франков (одно издание). Конечно же некоторые книги стоили дороже. В части коллекции Т.И. Вяземского, которая хранится в библиотеке Карадагской научной станции им. Т.И. Вяземского, инкунамбулы и палеотипы (книги, изданные с 1 января 1501 г. до 1 января 1551 г.) не сохранились, а они, безусловно, были. В библиотеке при жизни Т.И. Вяземского были уникальные издания, сохранившиеся всего в 2-3 экземплярах в мире! (Султанов, 1914. С. 2). Возможно, их цена могла бы доходить до 10000 франков. Нам еще предстоит открыть те сокровища библиотеки Т.И. Вяземского, места хранения которых пока не известны.

«Богатство библиотеки, - пишет С.Я. Елпатьевский, - можно оценить, когда случайным людям приходится обращаться к владельцу ее за теми или иными справками. Когда я заинтересовался Египтом, я нашел там редчайшие издания, которые, я не знаю, мог ли бы найти в московских и петербургских библиотеках (Елпатьевский, 1998. С. 77).

Спустя десятилетия ученые приезжали на Карадаг на поиски нужных им книг. Вот что об этом пишет заведующая библиотекой Карадагской биологической станции в 1953-1957 гг. Ольга Никандровна Овен (1927-2000): «После войны историческую литературу передали Крымскому филиалу Академии наук, медицинскую - Симферопольскому медицинскому институту. Но несмотря на это, ежегодно десятки ученых приезжали, чтобы поработать в библиотеке. Многие из них отмечали, что самые крупные книгохранилища страны не имеют тех книг, которые хранятся в библиотеке Т.И. Вяземского» (Овен, 1997. С. 53). Книговед и библиограф О.Н. Овен много сделала для приведения библиотеки в порядок: «Библиотека, 
вернее, то, что от нее сохранилось, так и не была толком разобрана и описана. - Пишет ее дочь Н.С. Косарева. - Мама заполнила тысячи карточек, постаралась привести, что могла, в порядок. Увы, таких увлеченных библиотекарей впоследствии не было, а после переезда в новое помещение библиотека Вяземского вернулась в прежнее состояние» (Косарева, 2008. С. 7.). Уточним, что библиотека хранилась в главном - научном здании станции, а затем ее перевели в помещение жилого корпуса (в настоящее время это административный корпус Карадагской научной станции им. Т.И. Вяземского, где и продолжает храниться библиотека).

Вернемся к характеристике библиотеки С.Я. Елпатьевским. «Сколько стоит эта библиотека - сто тысяч, двести тысяч, быть может больше, - я не знаю; но я никогда не слыхал о частной библиотеке в России, подобно этой библиотеке, которая собиралась с такой великой любовью и с такими великими жертвами. Человек собирал всю жизнь свою сокровищницу и, должно быть, долго мечтал, как мечтают русские люди, - мечтал о том, что будет его библиотека, что даст она...

И - что не часто случается с русскими людьми - мечта готова осуществиться. Внизу, под санаторией, на берегу моря уже выросло четырехэтажное здание, будущая биологическая станция. [...] Сюда же переселится как дар станции и огромная библиотека [...].- Пишет С.Я. Елпатьевский (Елпатьевский, 1998. С. 82).

К сожалению, станция смогла сохранить лишь часть огромной, ценной, уникальной библиотеки, но и эта часть представляет культурную ценность. Каждая книга, где бы она ни находилась, хранит память о своем владельце. Выразим надежду, что приблизительный состав библиотеки будет восстановлен по каталогу, в составлении которого примут участие все библиотеки-хранители коллекции Т.И. Вяземского, а также и частные лица, у которых волей судьбы оказались книги замечательного библиофила. Первые шаги в этом направлении сделаны. В 2008 г. увидел свет каталог русских книг гражданской печати частной библиотеки Т.И. Вяземского. В нем дано библиографическое описание 69 книг, сохранившихся на Карадаге, a в приложении помещен список из 29 книг русской гражданской печати библиотеки Т.И. Вяземского, хранящихся в Научной библиотеке Крымского федерального университета им. В.И. Вернадского (Каталог старопечатных..., 2008). К сожалению, приходится констатировать, что это всего лишь малые осколки обширного некогда книжного сокровища.

В сентябре 1913 г. в гостях у Т.И. Вяземского побывал зоолог Иван Иванович Пузанов (1885-1971). Он уже слышал о книжных сокровищах Карадага. Однако увиденное превзошло все ожидания. Встреча с Т.И. Вяземским стала важным событием в жизни И.И. Пузанова. Это чувствуется в благодарных, живых воспоминаниях, в которых мы являемся невольными свидетелями встречи и слышим голос самого Т.И. Вяземского. При осмотре библиотеки Т.И. Вяземский рассказывает И.И. Пузанову: «Вот, пожалуйста, полное собрание начиная с 1666 года "Мемуаров Королевского общества" - это англичане академию свою так называют. Вот полное собрание Французской академии, вот нашей Российской, с 1725 года - в самой академии некоторых томов нет, а у меня есть! - самодовольно улыбнулся библиофил своей детски доброй улыбкой. Вот труды научной экспедиции, снаряженной Наполеоном, когда он ходил завоевывать Египет... А вот и поновее издания, американские - труды института Карнеги» (Пузанов, 1960. С. 117-118).

Здесь важный штрих к характеристике личности библиофила - открытость библиотеки для посетителя, доброжелательность в отношении к нему. Высокомерие чуждо Т.И. Вяземскому - он в непринужденной, дружеской беседе рассказывает о своих культурных ценностях.

«Но где же это вы могли приобрести такие сокровища?» - С изумлением спрашивает И.И. Пузанов.

«А всюду, где только мог: и в Москве, на Сухаревке, и в Петербурге, но больше в Париже, на набережной Сены, у тамошних букинистов. У меня, знаете, страсть такая: как вырвусь за границу, в Париж, так сейчас же на набережную Сены, копаться в книжном хламе. Меня уже и букинисты старые там приметили: «Вот мол, le docteur russe» опять к нам пожаловал!». 
На вопрос о стоимости коллекции Т.И. Вяземский отвечает И.И. Пузанову: «И не спрашивайте! - отмахнулся Вяземский. - За некоторые издания тысячи франков платил..» (Там же. С. 118).

Для нас важно, что западноевропейские книжные культурные ценности русский доктор Т.И. Вяземский приобретал непосредственно в Европе.

Летом 1913 г. у Т.И. Вяземского целый месяц гостил его московский товарищ, общественный деятель, педагог Н.П. Розанов. В своих воспоминаниях он характеризовал Т.И. Вяземского как человека благородного, внимательного, ласкового по отношению ко всем окружавшим его людям. В небольшом санатории Т.И. Вяземского каждый чувствовал себя уютно: «Прежде всего [...] бросалась в глаза его ласковость по отношению ко всем его окружавшим, одетая в форму легкой шутливости. С каждым Терентий Иванович умел найти предмет для разговора, хотя бы люди, с которыми он весело и непринужденно беседовал, были гораздо ниже его в отношении умственного развития» (Розанов. 1914. С. 10).

Н.П. Розанов подметил культ книги, открытой для всех: «Особенно же ему нравилось вести с своими дачниками беседы на научные и литературные темы. Тут пред нами [он] выкладывал всю свою душу и давал нам много интересных и ценных сведений. Кроме того, он по разным поднимавшимся среди нас вопросам немедленно же указывал литературу предмета и обыкновенно увлекал нас в свою библиотеку, где и отыскивал подходящую для решения вопроса книгу или статью» (Там же. С. 10).

\section{К истории станции}

В июле 1907 г. Т.И. Вяземский и Л.З. Мороховец приступили к строительству станции. Вот что пишет о начале строительства А.Ф. Слудский: «Ни Т.И. Вяземский, ни Л.З. Мороховец не располагали большими средствами. Дело было начато без какого-либо основного капитала. Вяземский предоставил для будущей станции участок своего имения «Карадаг» [...] и свою библиотеку, которая уже к тому времени была очень обширна. Мороховец взялся доставлять исподволь необходимые средства для постройки. И тот и другой вложили в это дело всю свою душу, и лично, без архитекторов и техников разработали и стали проводить в исполнение план постройки [...]» (Слудский, 1917 1б. С. 9).

Т.И. Вяземский с первых дней строительства завел «Книгу для записей и расходов по строительству и оборудованию биологической станции “Карадаг”» (далее: Книга). Из заглавия узнаем, что первое название станции было - «Карадаг» и условно она планировалась как биологическая, но впоследствии, учитывая взгляды Т.И. Вяземского на развитие многих направлений естествознания и соответствующий состав его библиотеки, решено было создавать научную станцию. Для нас важны обстоятельства различных этапов строительных работ, в особенности - начальных, от их правильной организации зависела дальнейшая судьба стройки. В Книге читаем о сдельных работах, сданных по договорам в 1907 г.:

«I 20 июля. Подрядчик грек Паника принял работу по кладке здания станции по цене шестнадцать рублей [...] за кубическую сажень и шпунтовке каменных стен [...] по восемь рублей $[\ldots]$ за погонную сажень.

II июль 21. Подрядчик Абдеруим Мемет - оглы принял перевозку камня, сложенного в клетки [?] к месту стройки по 3 р[убля] 50 коп[еек] с куб[ической] сажени.

III июль 24. Рабочие Иван Ангелов и Григорий Моцаренко приняли на себя работу по выемке земли под здание станции по 3 р[убля] 75 коп[еек] за кубич[ескую] сажень. Работы закончены 7-го авг[уста] и деньги уплачены.

IV август 2. Подрядчик Абдеруим [1 слово неразборчиво] принял на себя доставку воды из реки Отузки по 35 коп[еек ] за бочку (40-ведерную).

$\mathrm{V}$ [август ] 2. Он же принял на себя доставку песку к месту стройки по 8 рубл[ей] за кубич[ескую] сажень.

VI. Плотник Савва принял на себя работу по изготовлению оконных и дверных коробок из нашего леса по 1 рубл[ю] за каждую штуку. 
VII. Владелец известкового завода в Судаке ... [имя не указано, Т.И. Вяземский оставил место, чтобы вписать, но не сделал этого впоследствии] принял на себя доставку сырой негашеной извести по 24 коп[ейки] за куб с его доставкой.

VIII. Сеит-Калиль [Халиль] взял на себя поставку 100 штук камня, размером 1 аршин длины, $1 / 2$ аршина ширины и $1 / 2$ аршина высоты. Он обязался доставить камень от места ломки на баркасе на берег биолог[ической] станции. Цена каждой штуки камня вместе с доставкой на берег моря 85 коп[еек].

IX. Плотник Савва условился изготовить оконных и дверных коробок по 1 рублю за каждую штуку» (Архив КБС. Оп. 1. Д. 22. Л. 2, 2 об.).

Интересно отметить некоторые детали. На Карадаге была проблема с водой, поэтому ее возили из не пересыхавшей в то время реки Отузки, расположенной приблизительно в 1 километре от станции. Во второй раз указан плотник Савва видимо потому, что согласился изготавливать дверные и оконные коробки по 1 рублю за штуку так же и из своего леса. Станцию строили представители разных национальностей - русские, украинцы, крымские татары, греки. Имена строителей не единожды упоминаются в переписке Л.З. Мороховца с Т.И. Вяземским.

В начале стройки Л.3. Мороховец был на Карадаге, в Москву уехал во второй половине августа 1907 г. На обороте отрезного купона на перевод Т.И. Вяземскому 45 рублей, датированном 28 августа пишет: «Сегодня утром благополучно добрался до Москвы [...] Присылайте скорее счет Паники и Абдераима. Посылаю Вам свой долг [...] (ЦИАМ. Ф. 1336. Оп. 1. Д. 99. Л. 3).

Т.И. Вяземский показал себя хорошим организатором и руководителем строительных работ. В достаточно короткие сроки, для небольшого количества рабочих, - до середины сентября была закончена кладка стен первого этажа (рис. 7). На радостях Т.И. Вяземский послал фотографии стройки в Москву. Вскоре от Л.З. Мороховца пришел ответ: «Дорогой Терентий Иванович! Вчера в лаборатории мы получили Ваши фотографии и все мы пришли в неописуемый восторг! Для меня фотографии были некоторым образом ясновидением, ибо они показывали рост того, что зачалось при мне! Мы не могли удержаться от того, чтобы не приветствовать Вас немедленно телеграммой! Поздравляем! Желаем с успехом закончить второй и третий этажи!» (ЦИАМ. Ф. 1336. Оп. 1. Д. 99. Л. 9).

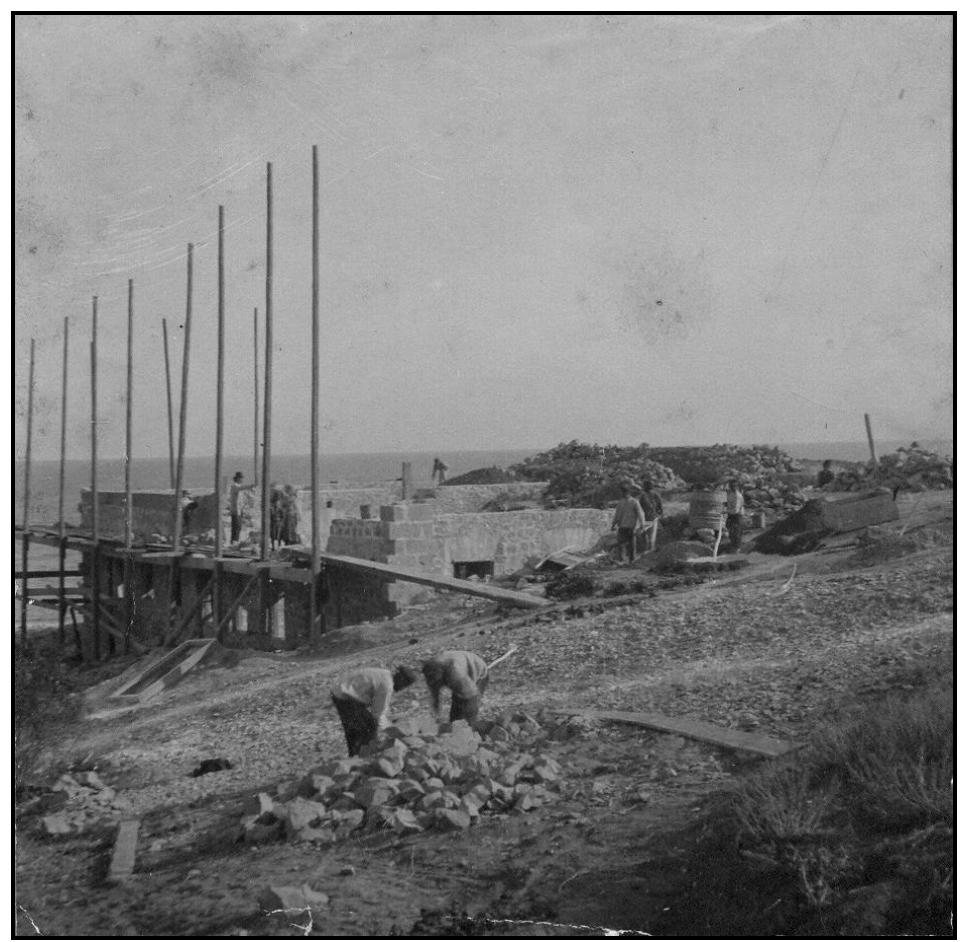

Рис. 7. Начало строительства станции в 1907 г. Т.И. Вяземский (в темной шляпе) среди рабочих. Фотография. Архив Карадагской биологической станции. 
Важно отметить, что первые строительные работы настолько укрепили уверенность Т.И. Вяземского в успешном завершении всего мероприятия по созданию станции, что мысленно он считал станцию уже выстроенной. В этом убеждает тот факт, что в начале августа 1907 г. он составил дарственную запись, согласно которой пожертвовал в собственность Московского университета свою библиотеку, «подробно обозначенную в каталогах и описях [...] Дар этот я, Вяземский учинил с тем условием, что вся означенная библиотека должна навсегда остаться в зданиях биолого-физиологической станции и должна обслуживать эту станцию» (ЦИАМ. Ф. 224. Оп. 1. Д. 66. Л. 6). Для Т.И. Вяземского 1907 г. стал годом рождения станции.

К сожалению, судьба каталогов, о которых упоминал Т.И. Вяземский, до настоящего времени неизвестна. Но остается надежда отыскать эти каталоги, - они могли быть библиофильскими, изданные мизерными тиражами в несколько десятков экземпляров. Каталоги не предназначались для библиотек, использовались самим Т.И. Вяземским и в качестве подарка - друзьям. Главная ценность таких каталогов в том, что они раскрывают индивидуальность собирателя книг, его портрет, в них сохраняются труды библиофила по формированию библиотеки. Каталог - это главный труд каждого библиофила и является памятником культуры.

Дар Т.И. Вяземского, по всей видимости, вызван был тем, что он хотел завершить строительство в сжатые сроки - за несколько лет. Для этого нужны были дополнительные средства: «[...]цену даримому мною движимому имуществу я, Вяземский определяю по совести в пятьдесят тысяч рублей» (Там же Л. 6). Цена по совести - символическая и для университета это был дар, а для Т.И. Вяземского такая сумма позволила бы построить и здание станции, и здание библиотеки! Нам неизвестны обстоятельства переговоров в отношении библиотеки. Можно предположить, что вопрос о даре Т.И. Вяземского был почти решен - тому находим подтверждение в тексте дарственной записи: «Явка у нотариуса М.М. Поповича в Старом Крыму» (Там же. Л. 6). Но что-то расстроилось, соглашение сорвалось, и дарственная запись нотариально утверждена не была. В дальнейшем, ориентировочно в 1912-1913 гг., когда строительство станции подходило к завершению, а строительство здания библиотеки находилось на начальном этапе, Т.И. Вяземский вновь предпринял попытку передать университету и библиотеку, и станцию (Михаленок, 2015). В переговорах с представителями университета активное участие принимал С.С.Крым, много сделавший для становления научной станции на Карадаге. «Библиотеку университет принять соглашался, - указывал C.С. Крым, - а на содержание станции средств не хватало. Удалось заручиться обещанием отдельных лиц и учреждений, но нужно было закончить прежде постройку» (Крым, 1917. С. 15).

Строительство станции ввиду отсутствия достаточных средств растянулось до 1913 г. включительно. Т.И. Вяземский надолго, до поздней осени, до наступления холодов задерживался на Карадаге, руководил строительством, разбирал книги своей библиотеки. Л.З. Мороховец приезжал в Карадаг на короткий срок в летнее время. Затем уезжал в Москву, где его ожидали лекции в университете. Впрочем, в строительных вопросах у Л.3. Мороховца было больше опыта, чем у Т.И. Вяземского. Так, в Москве, в 1890-1893 гг. он проектировал и строил здание Физиологического института (Макаров, Горелова, 1994. С. 50). Поэтому, строительством станции он так же, как и Т.И. Вяземский, руководил полноценно. В регулярно посылаемых на Карадаг письмах, давал советы, вносил некоторые изменения в строительные работы.

В ноябре 1907 г. строительные работы были приостановлены из-за наступления холодов. В письме от 18.11.1907 г. Л.3. Мороховец делает замечание по поводу того, что необходимо более подробно обсудить план строительства станции. Он выражает беспокойство о строительстве отдельного здания для библиотеки: «Пока мы с Вами не обсудим подробно план библиотеки, было бы непростительно предпринимать что либо по отношении к постройке библиотеки, а разрешить [...] зимою рыть канавы для стен библиотеки было бы просто преступлением с нашей стороны: разрыхлять, размачивать [...] грунт под библиотекой - никоим образом не допустимо! До наступления сухого времени нечего и думать трогать грунт под библиотекой» (ЦИАМ. Ф.1336. Оп. 1. Д. 99. Л. 25). Из писем Л.3. Мороховца узнаем, что Т.И. Вяземский планировал весной 1908 г. приступить к строительству здания для библиотеки, 
которое непосредственно примыкало бы к зданию станции с севера, а затем уже продолжать строительство собственно станции. Л.З. Мороховец согласился с мнением Т.И. Вяземского: «Я тоже думаю, что не следует весною вести здание кверху, а прежде всего приступить к возведению библиотеки, но только летом, а затем уже вести здание кверху - это во всех отношениях лучше» (Там же. Л. 25).

Тем не менее, начиная с 1908 г. предпочтение в строительстве было отдано зданию станции - его возводили вверх, а строительство библиотеки шло чрезвычайно медленно и в 1914 г. в библиотечном здании еще не было стен, в то время, как основное здание станции и жилой корпус были практически готовы к эксплуатации. Причины такого положения дел могут быть объяснены как отсутствием денежных средств, так и взаимоотношениями Т.И. Вяземского и Л.3. Мороховца. К 1912-1913 гг. между ними возникли серьезные разногласия в вопросах ведения строительства. В связи с этим, а также по причине болезни, Л.3. Мороховец постепенно стал отходить от дел по строительству станции и попросил Т.И. Вяземского вернуть ему средства, затраченные на строительство (15000 рублей). Затруднения по финансированию строительных работ разрешил С.С. Крым, предоставив Т.И. Вяземскому небольшой банковский кредит, что позволило продолжить в 1913 г. строительные работы.

Таким образом, дважды предпринимаемые неудачные переговоры с Московским университетом в отношении станции и библиотеки, требование Л.З. Мороховца вернуть ему деньги, затраченные на строительство, личные семейные неурядицы, отсутствие собственных средств для продолжения обустройства станции - вот те неблагоприятные условия, при которых будущее станции было поставлено под угрозу. В этой ситуации помог известный русский физик, товарищ председателя Общества содействия успехам опытных наук и их практических применений им. Х.С. Леденцова, состоящего при императорском Московском университете и императорском Московском техническом училище (далее: Общество) Николай Алексеевич Умов (1846-1915). Он настоятельно рекомендовал Т.И. Вяземскому поставить научную деятельность станции под эгиду Общества и много сделал, чтобы станция вошла в его состав (Бачинский, 1915. С. 29-30).

По совету Н.А. Умова, Т.И. Вяземский решил пожертвовать станцию и библиотеку в дар Обществу. Специально к экстренному заседанию Общества, намеченному на 25 марта 1914 г., Т.И. Вяземский готовит проект организации научной станции на Карадаге. Для нас он представляет особый интерес, как документ, в котором отражены пожелания Т.И. Вяземского об устройстве и деятельности станции. Послушаем Т.И. Вяземского:

\section{«ЗАДАЧИ, ПРЕСЛЕДУЕМЫЕ СТАНЦИЕЙ:}

1. Научная станция на Карадаге устраивается для содействия научным занятиям по всем отраслям естествознания и примыкающим к естествознанию наукам, а именно: общей биологии, зоологии, ботанике, бактериологии, физиологии, физике, механике, химии, геологии, палеонтологии, минералогии, петрографии, кристаллографии, агрономии, почвоведению, метеорологии, географии, антропологии, этнографии, антропологии [повторяется антропология, вероятно опечатка - нужно: археология?], океанографии и другим, а также их применению к задачам практики, и для распространения научных сведений в пределах указанного цикла наук.

Для достижения поставленных целей станция:

a) предоставляет свои помещения, приборы и библиотеку в пользование лиц, ведущих научную работу на станции, а также желающих усовершенствоваться по какому либо специальному отделу знания.

б) содействует в добывании соответствующего материала для работ.

в) сносится с учреждениями и лицами, как в России, так и за границей, в целях достижения задач станции.

г) издает Труды научной станции на Карадаге. 


\section{УПРАВЛЕНИЕ СТАНЦИЕЙ:}

Во главе станции стоит директор, избираемый Советом Общества имени Леденцова из числа членов Совета на три года простым большинством голосов. [....] Директор станции назначает по своему усмотрению заведующего станцией, на обязанности которого лежит хозяйственный надзор за станцией и заведывание библиотекой. Заведующий находится постоянно при станции и является исполнителем предписаний директора станции.

Директор станции является в то же время и редактором Трудов станции, причем для редактирования отдельных статей по вопросам вне его специальности, ему предоставляется входить в сношения с специалистами по соответствующему отделу науки, равно как и для руководства соответствующими специальными исследованиями.

Директор станции представляет в Совет Общества ежегодный отчет о состоянии и деятельности станции.

\section{О ДОПУЩЕНИИ К РАБОТАМ НА СТАНЦИИ:}

Право работать на станции предоставляется единоличной властью директора станции лицам без различия звания, национальности и пола, представившим ходатайство о допущении к работам на станции со стороны одного из ученых обществ, разрабатывающего науки в пределах указанного [...] цикла, а также соответствующих институтов и учреждений правительственных, общественных или частных. Право работать на станции дается на определенный срок, с обязательством для работающего лица представить к указанному сроку отчет о своей работе, а в случае, если таковая будет признана достойной печати, то печатать ее в Трудах Карадагской научной станции на Карадаге.

\section{О ДЕНЕЖНЫХ СРЕДСТВАХ СТАНЦИИ:}

На содержание станции Общество имени Леденцова отпускает ежегодно сумму в размере не менее семи тысяч рублей, из которых выдается вознаграждение директору станции 1500 p[ублей] и заведующему 1500 р[ублей]. Остальная сумма разносится директором по смете, каковая и утверждается ежегодно Советом Общества.

Капиталы, могущие быть пожертвованными научной станции на Карадаге, хранятся на том же положении как и все капиталы Общества, с тем, чтобы пожертвованные суммы [...] были употребляемы на нужды станции. Наличность собственных капиталов станции не освобождает Общество от обязанности отпускать указанную выше ежегодную сумму на содержание станции» (ЦИАМ. Ф. 224. Оп. 1. Д. 66. Л. 2, 2 об., 3).

Составной частью проекта была опись Карадагской научной станции. Отметим некоторые пункты, изложенные Т.И. Вяземским в описи: «Участок, занимаемый станцией, находится на берегу Черного моря, в Феодосийском уезде Таврической губ[ернии] близ деревни “Отузы” у подошвы горы Карадаг. Площадь участка две десятины девятьсот восемьдесят саж[еней] [...]».

Далее следует перечисление и техническая характеристика построек: здания станции, бетонной цистерны в земле и жилого здания. Затем Т.И. Вяземский указывает стоимость произведенных работ, которая «достигает приблизительно сорока тысяч рублей [...]». Участок земли, на которой размещена станция, он оценивает в пятьдесят семь тысяч восемьсот рублей. «Таким образом, пишет Т.И. Вяземский, - стоимость всего владения должна оцениваться не ниже девяноста семи тысяч восемьсот рублей [...]».

В завершении Т.И. Вяземский сообщает: «В случае, если Общество имени Х.С. Леденцова примет это владение, то Карадагской научной станции переходит, согласно прилагаемому документу, библиотека, собранная Т.И. Вяземским» (Там же. Л. 4).

В прилагаемой машинописной записке в Общество, Т.И. Вяземский пишет: «Сим имею честь довести до сведения Совета Общества [...] имени Леденцова, что мною приносится в дар названному Обществу принадлежащая мне библиотека, находящаяся ныне в имении моем «Карадаг» в Крыму, с тем, чтобы означенная библиотека была приурочена к переданной мною 
Обществу Карадагской научной станции и использована для обслуживания этой станции» (Там же. Л. 12).

Достаточно простая организация работы станции - директор станции - именитый ученый, находится в Москве, где отстаивает интересы станции в Обществе, заведующий станцией постоянно находится на Карадаге. Он заведует библиотекой, организовывает научную работу на станции путем приема ученых из России и других стран, осуществляет хозяйственную деятельность по станции.

При сравнении проекта Т.И. Вяземского и материалов по организации станции, составленных Обществом, видим, что Общество расширило и дополнило проект, изложив материал о станции в следующих позициях: организация Карадагской научной станции, инструкция заведующему Карадагской научной станции, утвержденная Советом Общества и правила для работающих на Карадагской научной станции (Временник Общества..., 1915. С. 5659). Вместе с тем, пункты, которые были важными для Т.И. Вяземского, оказались изменены, либо вовсе исключены из организационной структуры станции.

Например, был изменен пункт о содействии всем отраслям естествознания - на более узкий - «по различным отраслям естествознания (преимущественно по отделу биологии и геологии)» (Там же С. 56). Вместо директора «управление станцией поручается Попечительной комиссии, состоящей из председателя и двух членов, избираемых Советом общества [...]». Заведывание библиотекой из обязанностей заведующего было исключено и дана следующая неопределенная формулировка: «На обязанности заведующего лежит охрана библиотеки и установление порядка пользования ею (Там же. С. 58). Это была ошибка, приведшая в дальнейшем к утрате книг частной коллекции. Т.И. Вяземский считал библиотеку и станцию одним целым и такой подход, когда заведующий станцией является и заведующим библиотеки более предпочтителен в вопросах, касающихся сохранения станции и книг. Станция и библиотека были сохранены усилиями А.Ф. Слудского, но после его вынужденного ухода в 1927 г. с поста директора Карадагской научной станции им. Т.И. Вяземского, постепенно стали набирать обороты необратимые процессы в сфере непродуманной организации науки на Карадаге. То, чего так опасался Т.И. Вяземский - тлетворного влияния чиновников от науки на жизнь науки, привело в начале к передаче «непрофильных» книг в другие организации, а затем и фактическому закрытию в 1997 г. преемника станции - Карадагского филиала Института биологии южных морей Национальной академии наук Украины (далее: КФ ИнБЮМ). Кратко поясним ситуацию. В 1980-е гг. в отношениях КФ ИнБЮМ и Карадагского природного заповедника, созданного на базе КФ ИнБЮМ в 1979 г., стали возникать центробежные силы, направленные на выделение заповедника в качестве самостоятельного юридического лица. С учетом кризисных процессов в украинской академической науке, это привело к необоснованному закрытию КФ ИнБЮМ. Единоличной научной организацией на Карадаге стал заповедник, не являющийся преемником станции. Станции не было, но с завидным постоянством отмечали ее юбилеи (1999 г., 2004 г., 2009 г.). Критические замечания по поводу подготовки к столетнему юбилею несуществующей станции в 2014 г., прозвучали в наших работах (Михаленок, 2013. С. 407; Михаленок, 2014. С. 59). Этот непростой, дискуссионный вопрос, выходит за рамки нашей статьи.

Главная задача станции - выпуск печатных Трудов был исключен из пунктов по деятельности станции, взамен было предложено публиковать работы в изданиях Общества (Временник Общества..., 1915. С. 56). Впоследствии, в 1917 г. А.Ф. Слудский приложил огромные усилия, чтобы Труды станции вышли, как хотел того Т.И. Вяземский. И искренно радовался, когда вышел первый выпуск: «Ваши добрые вести меня просто потрясли: я так привык за последнее время ко всяким недобрым вестям, что вести добрые звучат для меня как голос с другой планеты. - Пишет А.Ф. Слудский из Карадага в Москву своему учителю, председателю Попечительной комиссии по станции, академику Алексею Петровичу Павлову (1854-1929). - И из всех вестей, конечно, выше и ценнее всех - известие о выходе выпуска Трудов. Вы не можете представить себе, как я боялся за этот выпуск! [...] Если бы наш выпуск не вышел, то это был бы такой удар, последствия которого трудно учесть. Поэтому известие о 
выходе выпуска для меня звучит как самая радостная весть о чудесном спасении близкого человека... Только с этого момента существование станции получает некоторый аргумент, который можно оценивать более высоко или менее высоко, критиковать, даже ругать, но который тем не менее имеет абсолютную ценность, как первый выявившийся результат десятилетних усилий по созданию станции. И я счастлив сейчас за Терентия Ивановича. Это начало его оправдания на суде истории. Нам с вами, верующим в начатое им дело, такого реально ощущаемого оправдания, быть может, и не нужно. Но вы знаете, сколько было неверующих!» (Архив РАН. Ф. 48. Оп. 2. Д. 98. Л. 4, 4 об.).

Станция заявила о себе в научном мире первым выпуском Трудов, идеи Т.И. Вяземского начинали воплощаться в жизнь. Этот выпуск сохранился во многих библиотеках бывшего СССР. В литературе о природе Карадага и истории станции, как правило, встречаются ссылки на этот выпуск (Труды Карадагской...,1917).

В дальнейшем Труды станции выходили нерегулярно, с перерывами. Последний выпуск Трудов, посвященный 80-летию станции, был издан в 1997 г. преемником станции КФ ИнБЮМ (Труды Карадагского...,1997). В нашей статье, опубликованной в Трудах КФ ИнБЮМ, была выражена надежда, что свет науки не угаснет на Карадаге (Михаленок, 1997. С. 143). Будем верить, что этот свет станет ярче.

Примечательно, что после многолетнего перерыва данный выпуск Трудов Карадагской научной станции им. Т.И. Вяземского выходит в преддверии знаменательной даты - 160-летия со дня рождения Т.И. Вяземского. Надеемся, что Труды станции станут выходить регулярно и в них будут отражены исследования, как того желал Т.И. Вяземский, - «по всем отраслям естествознания и примыкающим к естествознанию наукам».

Вернемся к проекту Т.И. Вяземского. Большинство членов Общества поддерживали проект - с ним они были ознакомлены заранее. Однако, буквально несколько человек настаивали на изменении некоторых пунктов проекта. Т.И. Вяземский знал об этой ситуации. Тем не менее, уважая мнение каждого ученого, спорить не стал, дабы не увязнуть в дискуссиях о передаче станции. Накануне экстренного заседания Общества 25 марта 1914 г., - 24 марта через А.Ф. Слудского, попросил снять проект с рассмотрения. Суть этого поступка лежит в основе личности Т.И. Вяземского. Очень точно подметил А.Ф. Слудский одну из главных ее особенностей: «[...]он действительно был другом людей, другом человечества - в этом была главная сущность и неотразимое обаяние его личности» (Слудский, 1917 1б. С. 7). В результате на правом поле первого листа проекта, рукой председателя Общества Семена Андреевича Федорова (1860-1934) оставлена запись карандашом: «А.Ф. Слудский 24 март[а] [1]914 от имени д-[окто]ра Т.И. Вяземского сообщил председ[ателю] О-[бщест]ва что он просит изъять этот проект организации пр[и] рассмотрении. Т.И. Вяземск[ий] не став[ит] никаких условий и обязатель[ств] О[бщест]ву при решении вопрос[а] [курсив наш]» (ЦИАМ.Ф. 224. Оп. 1. Д. 66. Л. 2).

На экстренном заседании Совета Общества обсуждался вопрос о возможности принятия дара Т.И. Вяземского - станции, участка земли при ней и библиотеки, насчитывающей более 40000 книг. В условиях дара было оговорено, что Общество должно заплатить Л.З. Мороховцу 15000 рублей в качестве покрытия затрат на строительство станции. Совет Общества выразил Т.И. Вяземскому глубокую благодарность за его ценное в научном отношении пожертвование, так как приобретение станции на оговоренных условиях, при гораздо большей цене предоставляемого Обществу владения, являлось по своей сути не покупкой, а пожертвованием. «Управление станцией предложено Т.И. Вяземскому, а обязанности его помощника А.Ф. Слудскому. Председателю комиссии по организации научной станции А.П. Павлову и ее членам выражена глубокая благодарность за понесенные ими труды», - читаем в материалах заседания (Временник. 1914. С. 7-11).

Движимый заботой о дальнейшей судьбе станции и имения, Т.И. Вяземский 16 мая 1914 г. посетил московского нотариуса Э.А. Шидловского с тем, чтобы составить свое духовное завещание. Душеприказчиками он назначил С.С. Крыма и А.Ф. Слудского. Так же он завещал своим друзьям - А.Ф. Слудскому и физику Алексею Иосифовичу Бачинскому (1877-1944) 
соответственно две и одну десятину земли с правом самостоятельного выбора участков. «Все остальное имущество мое, какое после меня останется как движимое, так и благоприобретенное недвижимое [...] я завещаю в собственность Обществу [...] имени Х.С. Леденцова на следующих условиях: а) прошу душеприказчиков моих немедленно по смерти моей принять в свое заведывание и управление все имущество мое и привести все мое состояние в срок не более трехлетнего со дня утверждения сего завещания к исполнению в полную известность; [...] г) по истечении трех лет со дня утверждения сего завещания к исполнению передать все имущество мое в выяснившихся к тому времени состоянии Обществу [...] в полное и неограниченное заведывание и распоряжение, при чем я выражаю пожелание, чтобы все завещанное мною Обществу движимое и недвижимое имущество служило целям и нуждам научной станции в Карадаге» (Архив КБС. Оп. 1. Д. 25. Л. 1 - 2).

Весь 1914 г. Т.И. Вяземский болел, однако не терял присутствие духа, заботился о будущности станции. Собрав силы, поехал на Карадаг. Вместе с А.Ф. Слудским, старался принимать участие в организации работ на станции.

Из первого отчета по станции за 1914 г. узнаем, что проводились исследования по изучению растительности, животного мира, геологии Карадага. Так же были завершены отделочные работы в жилом корпусе и обустроена небольшая биологическая лаборатория в верхнем этаже станции (ЦИАМ. Ф. 224. Оп.1. Д.66. Л. 44, 46 об.).

В целом, А.Ф.Слудский характеризует условия сезона «исключительно неблагоприятными для развития деятельности станции» (Там же. Л. 46). Он, в частности, отметил: «Болезнь заведующего станцией и ее основателя Терентия Ивановича Вяземского не позволила ему, как он надеялся, начать с ранней весны работы по завершению дела станции; далее работы были прерваны мобилизацией [началась Первая мировая война] и пришлось с большим трудом налаживать их снова. Еще позднее явилась неожиданная помеха - ураган и ливень 28 июля. Были прерваны пути сообщения и нанесены некоторые повреждения зданиям станции - выбиты стекла, сорвана железная крыша, побита черепица. Пришлось спешно ремонтировать [...] Условия военного времени вынудили окончить сезон много раньше. Тем не менее многочисленные запросы из разных местностей России свидетельствуют о том, что станция вызывает большой интерес [...] с будущего года начнется плодотворная работа» (Там же. Л. 46 об.).

Важно отметить, что для привлечения научных сил на Карадаг, Т.И. Вяземский планировал создать культурный поселок: «[...] [Т.И. Вяземский] мечтал о создании близ станции культурного поселка, - указывал А.Ф. Слудский, - и было, даже, время, когда он останавливался на мысли бесплатной раздачи в полную собственность небольших участков земли деятелям науки, под условием воздвижения постройки» (ЦИАМ. Ф. 224. Оп. 1. Д. 85. Л. 56).

«Терентий Иванович все лето болел и почти не встает с постели», - сообщал А.Ф. Слудский в письме от 27.07.1914 г. С.А. Федорову (Там же Л. 42). Основная нагрузка в проведении работ по станции легла на плечи А.Ф. Слудского.

Во второй половине августа 1914 г. Т.И. Вяземский приехал в Москву и окунулся в привычную - непривычную городскую жизненную суету. Он всегда старался, чтобы его болезненное состояние не рассмотрели окружающие его люди. Буквально за день до своей смерти вместе с Н.П. Розановым он ездил по важному делу в одно из имений Звенигородского уезда. Ничто не предвещало беды. Дорога вела через леса и поля. «Терентий Иванович, пишет Н.П. Розанов, - [...] пришел в прямой восторг от картины пожелтевших березовых лесов, какими мы проезжали. Он припоминал при этом свои юные годы, какие он прожил в деревне, с крестьянами, умилялся и желтыми листиками, и белою корою березы и всем видом самого простого русского проселка. Он как будто чувствовал, что последний раз любуется этими красотами родного пейзажа...» (Розанов, 1914. С. 12).

К кому, в какое имение ездил Т.И. Вяземский? Мы предполагаем, что он побывал в деревне Зайцево, в имении Анны Александровны и Алексея Лукича Лосевых. В семье Лосевых было пятеро сыновей и одна дочь. Знакомство Т.И. Вяземского с Лосевыми косвенно 
подтверждает то обстоятельство, что в его библиотеке сохранились книги с типографскими шрифтовыми экслибрисами А.А. Лосевой и одного из ее сыновей - Александра. Книги могли оказаться в библиотеке Т.И. Вяземского либо в качестве дара, либо в результате книгообмена. Так же, Т.И. Вяземский мог лечить кого-либо из семейства Лосевых. Отметим интересный факт - на дочери Лосевых Анне был женат известный художник Василий Николаевич Бакшеев (1862-1958), проживший в Зайцево около сорока лет (Лившиц, Попов, 1994, С. 196). Впрочем, наше предположение нуждается в дополнительном исследовании.

Т.И. Вяземский скончался от второго апоплексического удара 23 сентября 1914 г. в своей московской квартире в доме номер 6 по Ваганьковскому переулку. В этот день проходило заседание Совета Общества, на котором, еще не ведая о смерти Т.И. Вяземского, станции было присвоено имя ее создателя: «В день заседания Совета, 23 сентября, было намечено внести предложение о присвоении научной станции в Карадаге имени жертвователя Т.И. Вяземского, и в этом же заседании было получено известие о кончине Т[ерентия] Ив[анови]ча.

Собрание постановило присвоить научной станции имя ее основателя Т.И. Вяземского» (Временник Общества..., 1915. С. 43-44).

Отпевал Т.И. Вяземского в Крестовоздвиженской церкви на Возвиженке протопресвитер Московского Успенского собора Н.А. Любимов. Церковь, пишет И.П. Субботин, «была переполнена многочисленными представителями научных учреждений, обществ и другими лицами» (Субботин, 1914. С. 22). Похоронили Т.И. Вяземского на Пятницком кладбище в Москве. Неоднократно предпринимаемые нами поиски могилы пока не увенчались успехом.

После смерти Т.И. Вяземского, в его московской квартире была составлена опись имущества. Помимо различных вещей в опись были записаны книги. Так, 860 экземпляров различных книг и брошюр на русском и иностранных языках хранились в семнадцати ящиках и были оценены в 350 рублей (Архив КБС. Оп. 1. Д. 25. Л. 7). Также в шести ящиках хранились иностранные научные книги, оцененные в 150 рублей (Там же. Л. 8). Книги и часть иного имущества в ноябре 1915 г., как душеприказчик Т.И. Вяземского, получил А.Ф. Слудский (Там же. Л. 9). Не ошибемся, что это были книги, которые Т.И. Вяземский планировал перевезти на Карадаг.

Вернемся на Карадаг: пустынный, осенний, сумрачный, настороженный, осиротевший...

В сентябре 1914 г. уехал из Карадага в Москву А.Ф. Слудский. Сложилась непростая ситуация, когда некому было заботиться о сохранении станции и библиотеки. Помог Н.А. Маркс, проживавший в имении своих предков в деревне Отузы, недалеко от Карадага. В письме к Н.А. Марксу от 8.10.1914 г. председатель Общества С.А. Федоров обращается с «[...] покорнейшей просьбой [...] принять на себя временно заботы о целости и сохранении имущества [...] станции» (ЦИАМ. Ф. 224. Оп.1. Д. 66. Л. 53). В ответном письме С.А. Федорову от 29.10.1914 г. Н.А. Маркс не только подтверждает свое согласие, но и готов взять на себя дополнительные функции по обеспечению деятельности станции: «[...]помимо заботы о целости и сохранности станции во время отсутствия Александра Федоровича Слудского, охотно окажу посильное содействие всякому, кто в отсутствие г[осподина] Слудского, заедет сюда от имени Общества» (Там же. Л. 63). Мы благодарны этому человеку за бескорыстную заботу о станции.

А.Ф. Слудский следующим образом характеризовал суть научной станции на Карадаге: «Он [Т.И. Вяземский] стремился создать по возможности общедоступную базу в благоприятных для работы климатических и физико-географических условиях, на которых широкий круг лиц мог проводить научные исследования. Т.И Вяземский считал, что необходимо создать такое научное учреждение, в котором деятели науки могли бы проводить один-два месяца в спокойной обстановке, содействующей отдыху и укреплению здоровья. Не отрываясь, однако, от привычной научной работы. Такое учреждение не должно иметь узко-специального характера. Оно должно охватить широкий круг научных проблем и привлечь к себе исследователей различных специальностей, работающих в области естествознания. Неизбежный в таких случаях контакт 
между специалистами, работающими в смежных областях, должен явиться стимулом возникновения новых идей» (Архив КБС. Оп. 1. Д. 10 а. С. 1).

Станция была передана Т.И. Вяземским Обществу в незавершенном виде. Продолжателями его дела были Общество и заведующий станцией А.Ф.Слудский (Михаленок, 1999 1б.).

\section{Заключение (Вершина Вяземского)}

Т.И. Вяземский своим происхождением связан со многими поколениями русского сельского духовенства. Его отец Иван Терентьевич Вяземский (1803-1872) был священником деревни Путятино Раненбургского уезда Рязанской губернии. Т.И. Вяземский родился 20 апреля (крещен 21 апреля) 1857 г. в многодетной семье И.Т. Вяземского. Ему суждено было стать священником. В 1873 г. он закончил Раненбургское духовное училище, затем в 1878 г. четыре класса Рязанской духовной семинарии, перешел в пятый класс (рис. 8). В России, вплоть до 1879 г., после четырехклассного общеобразовательного курса обучения в семинариях (всего в семинариях было шесть классов) семинаристы, по своему выбору, могли поступать в светские высшие учебные заведения. Т.И. Вяземский изъявил желание поступить на медицинский факультет Московского университета. В июле 1878 г. он был уволен из духовно-училищного ведомства с обязательством возвратить «духовному ведомству сумму, употребленную на его содержание в семинарии [...] четыреста тридцать четыре рубля [...]» (ЦИАМ. Ф. 418. ОП. 292. Д. 77. Л. 2 об).

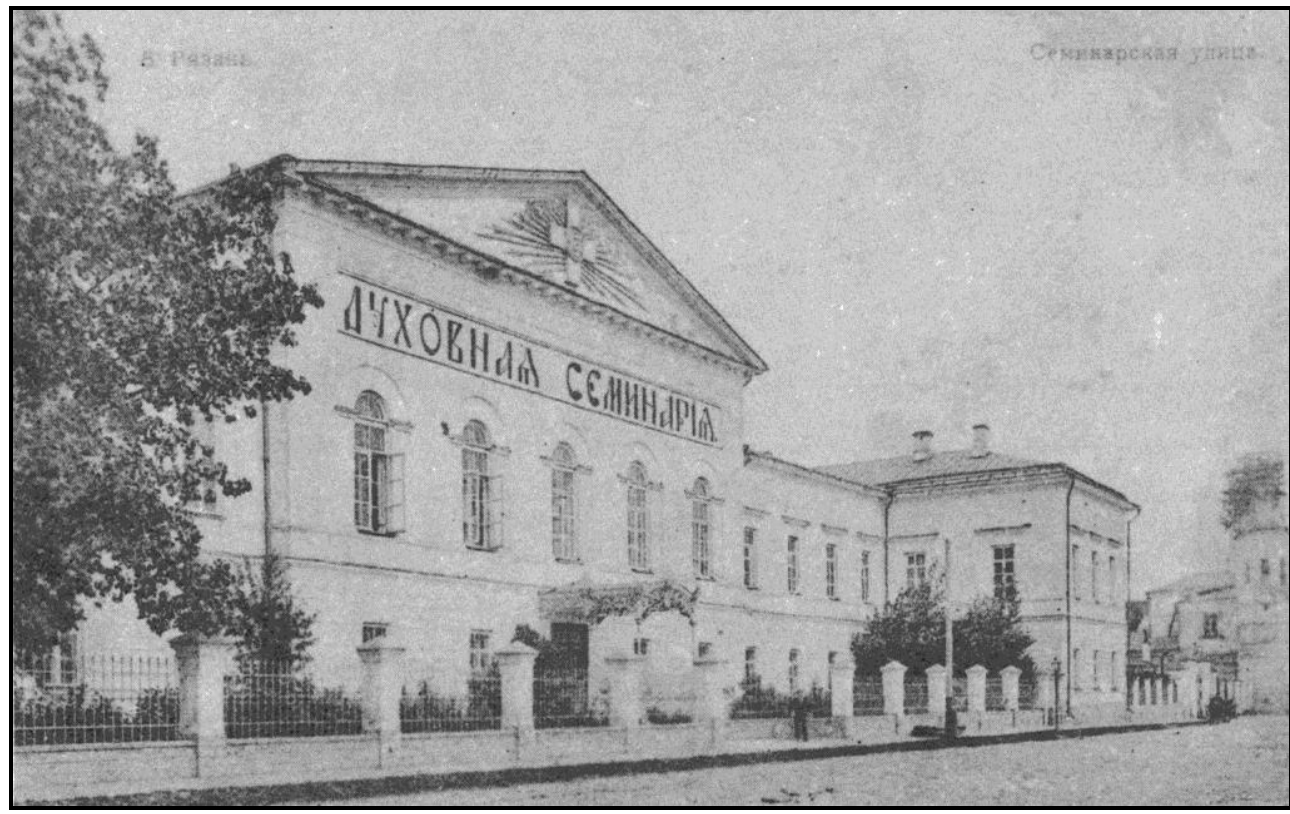

Рис. 8. Здание Рязанской духовной семинарии в Рязани, где в 1873-1878 гг. учился Т.И. Вяземский. Открытка конца XIX в.

12 августа 1878 г. Т.И. Вяземский пишет прошение на имя ректора Московского университета: «Желая, для продолжения образования, поступить в Московский университет, имею честь покорнейше просить Ваше превосходительство сделать зависящее распоряжение о принятии меня в число студентов на I-й курс медицинского факультета, на основании прилагаемых при сем документов [...] При сем, на основании § 100 Высочайше утвержденного Университетского устава, обязуюсь все время пребывания моего в университете подчиняться правилам и постановлениям университетским» (ЦИАМ. Ф. 418. Оп. 292. Д. 77. Л. 1).

Т.И. Вяземский мог стать священником, но стал врачом.

Разработанные Т.И. Вяземским предупредительные меры по борьбе с алкоголизмом, могут быть применены в различных странах. Впервые в России, в 1909 г. им была выпущена библиография по алкоголизму (Вяземский, 1909), являющаяся библиографической редкостью. 
В случае переиздания, библиография с успехом может быть использована медиками и историками науки.

В своей практической деятельности врача на Кавказских минеральных водах он применял электротерапевтические методы, на основе собственных исследований, не имевших аналогов ни в России, ни за рубежом. Этот существенный вклад в развитие отечественной бальнеологи должным образом не оценен.

Т.И. Вяземский первый установил, что 100-летие Кавказских минеральных вод следует отмечать не в 1898 г., а в 1903 г. В 2003 г. отметили 200-летие Кавказских минеральных вод, но о Т.И. Вяземском не вспомнили. Надеемся, что наша статья, раскрывшая причины такого положения, поможет восстановить историческую справедливость - вернет имя Т.И. Вяземского в сферу истории Кавказских минеральных вод.

Принято считать, что главным делом в жизни Т.И. Вяземского была выстроенная им станция. Это не совсем так - станция последнее главное дело в жизни Т.И. Вяземского. Другие главные его дела - библиотека, врачебная деятельность, борьба с алкоголизмом, электротерапия, история Кавказских минеральных вод, работа в институте имени П.Г. Шелапутина - то, о чем мы кратко рассказали. Объем статьи не позволил рассказать об иных, также главных делах Т.И. Вяземского, в том числе и не реализованных. В широком спектре интересов и состоит особенность творческой личности Т.И. Вяземского, не ограничивающего себя какой-либо областью знания. При этом, подход к каждому предпринимаемому им делу был по-настоящему профессионален, дилетантство было чуждо Т.И. Вяземскому.

Основой всех его главных и второстепенных дел были книги, собранные с большой любовью и предназначенные для деятельности станции. Дружба с известным библиофилом П.В. Щаповым сформировала культуру его книжного собирательства. Без частной библиотеки Т.И. Вяземского, насчитывавшей, согласно разным источникам, от 30 тысяч до 50 тысяч книг, не было бы и станции. Ее стены возводились ради книг. Передача части книг в другие библиотеки Крыма связана, главным образом, с дилетантским подходом к пониманию книговедческого, культурного значения книги со стороны тех руководителей станции, при которых книги покидали Карадаг. Как здесь не вспомнить пожелание Т.И. Вяземского о том, чтобы книги навсегда оставались на Карадаге, а заведующий станцией был и заведующим библиотекой.

На Карадагской научной станции им. Т.И. Вяземского необходимо выделить коллекцию книг в качестве мемориальной и, наряду с другими исследованиями по различным направлениям естествознания, проводить книговедческие и библиографические. Здесь не обойтись без тесного сотрудничества с Научно-исследовательским отделом редких книг (Музея книги) Российской государственной библиотеки.

Общество содействия успехам опытных наук и их практических применений им. Х.С. Леденцова при Московском университете и Московском техническом училище много сделало для становления работ на станции с 1914 г. вплоть до своего закрытия в 1918 г. В трудное время, когда Л.З. Мороховец в связи с болезнью отошел от дел по строительству станции и попросил вернуть деньги, затраченные им на строительство, Общество, по сути, спасло репутацию Т.И. Вяземского, приняв станцию в дар (стоимость станции, библиотеки и земли намного превышали сумму долга) с условием выплаты долгов. В 2002 г. Общество было возрождено, сотрудничество с ним пока не налажено.

Для привлечения исследователей необходимо не только снабдить Карадагскую научную станцию им. Т.И. Вяземского современными приборами и оборудованием, но и создать комфортные условия для проживания и работы. В этой связи целесообразно вернуться к идее Т.И. Вяземского о создании культурного поселка и возобновить работу санатория.

В 1999 г., исследуя названия вершин Карадагского массива по различным топографическим картам и литературным источникам, мы пришли к выводу, что одну из вершин необоснованно, случайно назвали Малым Карадагом в середине XX века. На топографических картах ее не обозначали. Название прижилось в большей мере среди местного 
населения. Поэтому, на наш взгляд, было бы уместно назвать северо-западный отрог (Малый Карадаг) горы Святой - вершиной Вяземского (Михаленок, 1999 1а). Наше предложение пока официально не закреплено на топографической карте.

Здание станции хранит мечту Т.И. Вяземского о царстве науки на Карадаге, символизируя собой культурную вершину Вяземского. Остается надежда, что исследователи, путешествующие по тропам знания и науки, откроют для себя новый маршрут - к Карадагской научной станции им. Т.И. Вяземского.

Автор выражает признательность всем, кто оказал содействие и помощь в работе с архивными материалами: директору КФИнБЮМ в 1989-1997 гг. Петру Григорьевичу Семенькову, дирекции и научному сотруднику Архива РАН - Наталье Викторовне Литвиной, дирекции и сотрудникам ЦИАМ.

\section{Список литературы}

1. Бачинский А.И. Николай Алексеевич Умов // Временник Общества содействия успехам опытных наук и их практических применений им. Х.С. Леденцова, состоящего при императорском Московском университете и императорском Московском техническом училище. - М., 1915. - Вып. 1. - С. 1-32.

2. Белкин Р.И. Карадагская биологическая станция (К двадцатипятилетию существования // Успехи современной биологии. - 1940. - т.XII. - Вып. 1. - С. 160-171.

3. Богословский В.С. К вопросу о столетии Кавказских минеральных вод (письмо к издателю) // Записки Русского бальнеологического общества в Пятигорске. CXV заседание 26 мая 1899 г. - Пятигорск: тип. А.М. Мануйлова, 1899. - С. 547-549.

4. Верещагин В.А. Русский книжный знак. - СПб: печатня Р. Голике, 1902. - 125 рис.

5. Вернадский В.И. Из истории идей. - М.: Типо-литография т-ва Кушнерев и $\mathrm{K}^{0}$, Пименовская ул., соб. дом, 1912. - 18 с.

6. Воробьева Е.В., Шицкова Л.Б. О реконструкции библиотеки П.В. Щапова в русской части фонда отдела редких книг ГПИБ / Вивлиофика: История книги и изучение книжных памятников. Вып. 1. / Сост. Самарин А.Ю. - М.: Пашков дом, 2009. - С. 146-154.

7. Временник Общества содействия успехам опытных наук и их практических применений им. Х.С. Леденцова, состоящего при императорском Московском университете и императорском Московском техническом училище. - М.,1914. - Вып. 2. - С. 7-11.

8. Временник Общества содействия успехам опытных наук и их практических применений им. Х.С. Леденцова, состоящего при императорском Московском университете и императорском Московском техническом училище. - М., 1915. - Вып. 1. - 112 с.

9. Вяземский Т.И. О желательном устройстве водяных электрических ванн в Кисловодске // Протоколы заседаний Русского бальнеологического общества в Пятигорске / IV протокол заседания Русского бальнеологического общества в Пятигорске. - Пятигорск: тип. А.М. Байкова, 1885. С. 36-44.

10. Вяземский Т.И. О распределении токов в диполярных гидроэлектрических ваннах // Протоколы заседаний Русского бальнеологического общества в Пятигорске / XXIV заседание Русского бальнеологического общества в Пятигорске, 29 августа 1887 года. Пятигорск: тип. А.М. Байкова, 1887. - С. 2-25.

11. Вяземский Т.И. Об определении силы тока проходящего через человеческое тело при применении диполярных ванн // Протоколы заседаний Русского бальнеологического общества в Пятигорске / XVIII заседание Русского бальнеологического общества в Пятигорске, 9 июня 1888 года. - Пятигорск: тип. А.М. Байкова, 1888 а. - С. 5-12.

12. Вяземский Т.И. Локализованные поражения коры головного мозга // Протоколы заседаний Русского бальнеологического общества в Пятигорске / XXXI заседание Русского бальнеологического общества в Пятигорске, 16-го июля 1888 года. - Пятигорск: тип. А.М. Байкова, 1888 б. - С. 1-16 
13. Вяземский Т.И. Об электрических явлениях, обнаруживающихся при применении Кавказских минеральных вод // Протоколы заседаний Русского бальнеологического общества в Пятигорске / XXXVII заседание Русского бальнеологического общества в Пятигорске 10 июля 1889 года. - Пятигорск: тип. А.М. Байкова, 1889. - С. 26-45.

14. Вяземский Т.И. Вероятные границы ошибок в определении силы тока при применении водяных диполярных ванн // Протоколы заседаний Русского бальнеологического общества в Пятигорске / XLVII заседание Русского бальнеологического общества в Пятигорске 17 августа 1890 года. - Пятигорск: тип. А.М. Байкова, 1890. - С. 1-25.

15. Вяземский Т.И. Критическая оценка опытных данных Скутетена по вопросу об электрических обнаружениях в воде минеральных источников // Минеральные воды / Под ред. В.С. Богословского и Т.И. Вяземского. - Пятигорск, 1895. - № 1. - С. 1-13.

16. Вяземский Т.И. Земные электрические токи (по поводу изучения влияния серных терм на организм). Читано в заседании Русского бальнеологического общества 5 августа 1898 года / Отдельный оттиск из Записок Русского бальнеологического общества в Пятигорске. Пятигорск: тип. А.М. Мануйлова, 1898 - 1899. - № 7. - 10 с.

17. Вяземский Т.И. К вопросу о столетии Кавказских минеральных вод (Посвящается памяти военного врача Петра Ивановича Шателовича). - М.: Унив. тип., Страстной бульвар, 1899. $14 \mathrm{c}$.

18. Вяземский Т.И. Электрические явления растений. - М.: Унив. тип., 1901. - Ч. 1. - 134 с.

19. Вяземский Т.И. К вопросу о столетии Кавказских минеральных вод (Посвящается памяти военного врача Петра Ивановича Шателовича). - Изд. второе. - М.: тип. Г. Лисснера и А. Гешеля. Воздвиженка, Крестовоздвиж. пер., д. Лисснера, 1903. - 16 с.

20. Вяземский Т.И. Библиография по вопросу об алкоголизме. - М.: тип. имп. Моск. ун-та, 1909. - Вып. 1. - 16 с.

21. Вяземский Т.И. Возможна ли в России борьба с алкоголизмом. - М.: тип. имп. Моск. ун-та, 1911 a. -16 c.

22. Вяземский Т.И. Кружок деятелей по борьбе со школьным алкоголизмом и противоалкогольный музей при кружке. - М.: печатня А.И. Снегиревой, 1911 б. - 18 с.

23. Вяземский Т.И. Вырождение и алкоголизм. - М.: Тип. Штаба моск. военного округа, 1913 . $-[2], 16, \mathrm{XI}$ c.

24. Дебаты по поводу доклада д-ра Т.И. Вяземского: «К вопросу о столетии Кавказских минеральных вод», происходившие 16 марта 1899 года в заседании московского отдела Общества охранения народного здравия // Записки Русского бальнеологического общества в Пятигорске / CXV заседание 26 мая 1899 года. - Пятигорск: тип. А.М. Мануйлова, 1899. - С. 527-556.

25. Дневник Высочайше разрешенного 1-го всероссийского съезда деятелей по климатологии, гидрологии и бальнеологии / Под ред. проф. Ф.И. Пастернацкого и д-ра м[едицины] В.О. Губерта. - № 1. - 27 ноября 1898 г. - СПб.: тип. П.П. Сойкина, Стременная ул., № 12. $12 \mathrm{c}$.

26. Елпатьевский С.Я. Крымские очерки. Год 1913-й. - Феодосия: Издат. дом «Коктебель» (Биб-ка альманаха «Крымский альбом»), 1998. - Вып. 4. - 144 с.

27. [Ермолов А.С.] К вопросу о переустройстве Кавказских минеральных вод в связи с общим положением бальнеологического дела в России и за границею. Записка министра земледелия и государственных имуществ. - СПб: Тип. Киршбаума, 1898. - [IV], 150 с.

28. Иваск У.Г. Описание русских книжных знаков. - М.: тип. Г.И. Простакова и типолитография И.И. Пашкова, 1905. - Вып. 1. - 176 с.

29. Кавказские минеральные воды. Пятигорск. Железноводск. Ессентуки. Кисловодск. К столетнему юбилею 1803-1903 г. - СПб.: Т-во Р. Голике и А. Вильборг, 1904. - 297 с. ил.

30. Кавказские минеральные воды. К 200-летию основания. «Памятники отечества». Альманах. - М.: Молодая гвардия, 2001. - № 49. - 192 с.

31. Калмыкова М.М. Личные книжные собрания в фондах Научной библиотеки Таврического национального университета имени В.И. Вернадского (1918-1940): к 95-летию основания 
Таврического университета / Под ред. А.А. Непомнящего. - Симферополь: ДИАЙПИ, 2013. $-312 \mathrm{c}$.

32. Каталог старопечатных изданий. Русские книги гражданской печати (1760-1825) библиотеки Т.И. Вяземского / авт. - сост.: Д.К. Михаленок, В.Ю. Лапченко, Л.В. Веселовская, О.А. Акимова; отв. ред. И.Ю. Фоменко. - Севастополь: ЭКОСИ Гидрофизика, 2008. - 216 с.

33. Косарева Н.С. Воспоминания дочери / Книга и человек: Сборник, посвященный 80-летию О.Н. Овен. - Тверь: Твер. гос. ун-т, 2008. - Вып 1. - С. 4-10.

34. Крым С.С. Терентий Иванович Вяземский. Встречи и воспоминания // Труды Карадагской научной станции им. Т.И. Вяземского. - 1917. - Вып. 1. - С. 12-17.

35. Лапченко В.Ю., Михаленок Д.К. Библиотека Т.И. Вяземского - гордость Карадага // Карадаг. История, геология, ботаника, зоология (Сборник научных трудов, посвященный 90-летию Карадагской научной станции им. Т.И. Вяземского и 25-летию Карадагского природного заповедника) Книга 1-я. - Симферополь: СОНАТ, 2004. - С. 44-52.

36. Лившиц А.С., Попов И.И. Зайцево / Одинцовская земля / Серия «Энциклопедия сел и деревень Подмосковья». - М.: Энциклопедия российских деревень, 1994. - С. 195-196.

37. Макаров В.А. Горелова Л.Е. История Физиологического института Московского университета // Проблемы социальной гигиены и истории медицины. - 1994. - № 4. - С. 4953.

38. Медушевская О.М. Теоретические проблемы источниковедения. М., 1976. - 125 с.

39. Михаленок Д.К. К 80-летию создания Карадагской научной станции им. Т.И. Вяземского / Труды Карадагского филиала института биологии южных морей им. А.О. Ковалевского НАН Украины: Сб. научн. тр. / НАН Украины, Карадагский филиал ИнБЮМ им. А.О. Ковалесвкого. Под ред. Н.А. Давидовича, В.А. Емельянова. - Севастополь: ЭКОСИ Гидрофизика, 1997. - С.134-144.

40. Михаленок Д.К. Вершина Вяземского / Карадагский калейдоскоп. Калейдоскоп литературы, науки, искусства. Версия 1. - Симферополь: Таврия, 19991 а. - С. 13-18.

41. Михаленок Д.К. Свет науки: 85 лет Карадагской научной станции имени Т.И. Вяземского / Карадагский калейдоскоп. Калейдоскоп литературы, науки, искусства. Версия 1. Симферополь: Таврия, 1999 1 б. - С. 19-42.

42. Михаленок Д.К. К истории Карадагской научной станции им. Т.И. Вяземского (по материалам архива РАН) / Фундаментальная наука: проблемы изучения, сохранения и реставрации документального наследия: Материалы Международной научной конференции / Отв. ред. В.Ю. Афиниани. М.: Архив РАН, 2013. С. 403-409.

43. Михаленок Д.К. Библиотека, «которая могла бы быть украшением любого университета» (о Т.И. Вяземском и его коллекции) // Румянцевские чтения - 2014. Ч. 2: материалы международной конф. (15 - 16 апр. 2014): [в 2 ч.] / Российская гос. б - ка; [редкол.: Л.Н. Тихонова, Е.А. Иванова, И.И. Шестопалов]. - М.: Пашков дом, 2014. - С. 55-60.

44. Михаленок Д.К. К истории научной библиотеки в Карадаге в 1905-1914 гг. // XV Таврические научные чтения (30 мая 2014 г., Симферополь): сборник научных статей. Часть 1. [в 2 ч.] / гл. ред. Е.Б. Вишневская. - Симферополь: ГБУ «Центральный музей Тавриды», 2015. С.123-131.

45. Михаленок Д.К., Лапченко В.Ю. Российские книжные знаки в частной библиотеке Т.И. Вяземского // Румянцевские чтения - 2012. Ч. 2: материалы Всероссийской науч. конф. (17-18 апр. 2012): [в 2 ч.] / Российская гос. б - ка; [сост.: Е.А. Иванова]. - М.: Пашков дом, 2012. - C. 43-49.

46. Михаленок Д.К., Лапченко В.Ю. Страницы истории частной библиотеки Т.И. Вяземского (1945-1975) // XII Таврические научные чтения (Симферополь, 27 мая 2011 г.): сб. статей. Ч.1. [в 2 ч.] / ред.-сост. Е.Б. Вишневская. - Симферополь: КРУ «Центральный музей Тавриды», 2012. - С. 133-140. 
47. Новосадский Н.И. Экскурсия слушателей Московского археологического института на места древнегреческих колоний северного побережья Черного моря в июле-августе 1910 года. - М.: печатня А.И. Снегиревой, 1910. - 16 с.

48. Овен О.С. Библиотека Т.И. Вяземского // Дни славянской письменности и культуры: Сб. докл. и сообщ. - Тверь, 1997. - Вып. 3. - С. 49-53.

49. Поддубный М.В. Забытое имя: приват-доцент Т.И. Вяземский // Исторический вестник Московской медицинской академии им. И.М. Сеченова. - 1993 . - Т. 2. - С. 29-41.

50. Пузанов И.И. По нехоженому Крыму. - Москва: Гос. изд-во геогр. лит., 1960. - 287 с.

51. Розанов Н.П. Памяти Т.И. Вяземского // В борьбе за трезвость. - 1914. - №5. - С. 7-13.

52. Симони П.К. Московский библиофил П.В. Щапов (1848-1888) / Альманах библиофила / Ленинградское общество библиофилов. - Ленинград: тип. Акад. художеств, 1929. - С. $237-$ 241. [Репринтное переиздание].

53. Святловский В.В. Кавказские минеральные воды (К столетнему юбилею Кавказских минеральных вод). Во врачебном, историческом, геологическом, этнографическом и друг. отношениях, с приложением очерка как надо пить минеральную воду и купаться в ней. Составил В.В. Святловский, б[ывший] врач Управления Кавказских минеральных вод. Екатеринослав: Изд. М.С. Копылова, 1898. - [III], 341 с.

54. Слудский А.Ф. Карадаг (в Крыму), его естественноисторическое значение, научная и промышленная будущность // Временник Общества содействия успехам опытных наук и их практических применений им. Х.С. Леденцова, состоящего при императорском Московском университете и императорском Московском техническом училище. - М., 1913. - Вып. 2. С. 35-52.

55. Слудский А.Ф. «Карадагская научная станция (исторические очерки)». Рукопись. [19341935]. - 26 с. [Хранится в библиотеке Карадагской научной станции им. Т.И. Вяземского. Инв № 108].

56. Слудский А.Ф. Терентий Иванович Вяземский // Труды Карадагской научной станции имени Т.И. Вяземского / Под ред. И.А. Каблукова и А.Ф. Слудского. - М.: Тип. Т-ва Рябушинских, 1917 1а. - Вып. 1. - С. 5-6.

57. Слудский А.Ф. Терентий Иванович Вяземский, как основатель Карадагской научной станции // Труды Карадагской научной станции имени Т.И. Вяземского / Под ред. И.А. Каблукова и А.Ф. Слудского. - М.: Тип. Т-ва Рябушинских, 1917 1б. - Вып. 1. - С. 7 11.

58. XLVII экстраординарное заседание Русского бальнеологческого общества в Пятигорске 3 сентября 1890 года // Протоколы Русского бальнеологического общества в Пятигорске. Пятигорск: тип. А.М. Байкова, 1890. - 5 с.

59. Субботин И.В. Д-р мед. Т.И. Вяземский в борьбе с алкоголизмом // В борьбе за трезвость. 1914. - № 5. - С. 14-23.

60. Султанов С. Карадагская сказка // Утро России. - 1913. - № 191. - С. 2.

61. Труды высочайше утвержденного первого всероссийского съезда деятелей по климатологии, гидрологии и бальнеологии. - СПб.: тип. П.П. Сойкина, Стремянная 12, 1899. - T. 1. - [LXXXVI], 850 c.

62. Труды Карадагской научной станции имени Т.И. Вяземского / Под ред. И.А. Каблукова и А.Ф. Слудского. - М.: Тип. Т-ва Рябушинских, 1917. - Вып. 1. - 113 с.

63. Труды Карадагского филиала Института биологии южных морей им. А.О. Ковалевского НАН Украины: Сб. научн. тр. / НАН Украины, Карадагский филиал ИнБЮМ им. А.О. Ковалеского. Под ред. Н.А. Давидовича, В.А. Емельянова. - Севастополь: ЭКОСИ Гидрофизика, 1997. - 224 с.

64. Чернопятов В.И. Материалы к родословию и семейной хронике Чернопятовых. Собирал Виктор Чернопятов. - М.: Тип. А.П. Петцман, 1914. - 430 с. 


\section{Архивные материалы}

1. Архив Карадагской биологической станции при ФГБУН «Карадагская научная станция им. Т.И. Вяземского - природный заповедник РАН» (Далее: Архив КБС). Оп. 1. Д. 3 а.

2. Архив КБС. Оп. 1. Д. 10 а.

3. Архив КБС. Оп. 1. Д.22.

4. Архив КБС. Оп. 1. Д. 25.

5. Архив Российской академии наук. (Далее: Архив РАН). Ф. 48 (А.П. Павлов). Оп. 2. Д. 98.

6. Центральный исторический архив Москвы. (Далее: ЦИАМ). Ф. 224 (Общество содействия опытных наук и их практических применений имени Х.С. Леденцова, состоящее при императорском Московском университете и императорском Московском техническом училище). Оп. 1. Д. 66.

7. ЦИАМ. Ф. 224. Оп. 1. Д. 85.

8. ЦИАМ. Ф. 418 (Императорский Московский университет). Оп. 292. Д. 77.

9. ЦИАМ Ф. 1336 (Т.И. Вяземский). Оп. 1. Д. 5.

10. ЦИАМ Ф. 1336.ОП. 1. Д. 63

11. ЦИАМ Ф. 1336. Оп. 1. Д. 99

12. ЦИАМ Ф. 1336. Оп. 1. Д. 114.

13. ЦИАМ Ф. 1336 Оп. 1. Д. 115.

Поступила 21 июля 2016 г.

В окончательном виде 29 августа 2016 г.

\section{TERENTY IVANOVICH VYASEMSKY \\ (TO THE 160 ANNIVERSARY SINCE BIRTH) \\ D.K. Mikhalenok \\ Feodosia, Russian Federation, dmikhalenok@gmail.com}

Certain fields of activity of T.I. Vyazemsky, Doctor of Medicine, bibliophile and founder of the Karadag Scientific Station are discussed. T.I. Vyasemsky believed that culture should be the base of the society development. He proposed series of propedeutic measures against alcohol dependence that are still important. T.I. Vyazemsky took part in the activity of the Russian Balneological Society in Pyatigorsk City. His research in the field of electrotherapy remains relevant till present days. He also found important historical fact - he identified that the year of foundation of the Caucasian Mineral Waters was 1803, but not 1798. This date is totally recognized now but the name of its founder T.I. Vyazemsky is forgotten. He collected great number of books in various fields of natural sciences, and his library had to become a basis and corner stone of the scientific station built by him. At the close of his days T.I. Vyazemsky donated the station and his library to the Kh.S. Ledentsov Society. On the basis of the analysis of archival materials and references little-known pages of the T.I. Vyasemsky`s biography are determined.

Key words: T.I. Vyazemsky Karadag Scientific Station, Kh.S. Ledentsov Society, Caucasian Mineral Waters, school-age alcoholism, T.I. Vyazemsky`s private library, «Karadag» estate. 